\title{
Variable risk preferences in new firm growth and survival
}

Karl Wennberg, Frederic Delmar and Alexander McKelvie

\section{Linköping University Post Print}

\section{Tweet}

N.B.: When citing this work, cite the original article.

Original Publication:

Karl Wennberg, Frederic Delmar and Alexander McKelvie, Variable risk preferences in new firm growth and survival, 2016, Journal of Business Venturing, (31), 4, 408-427.

http://dx.doi.org/10.1016/j.jbusvent.2016.05.001

Copyright: Elsevier

http://www.elsevier.com/

Postprint available at: Linköping University Electronic Press

http://urn.kb.se/resolve?urn=urn:nbn:se:liu:diva-130401

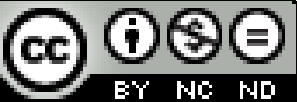


VARIABLE RISK PREFERENCES IN NEW VENTURE GROWTH AND SURVIVAL

Journal of Business Venturing (2016), vol. 31, pp. 408-427.

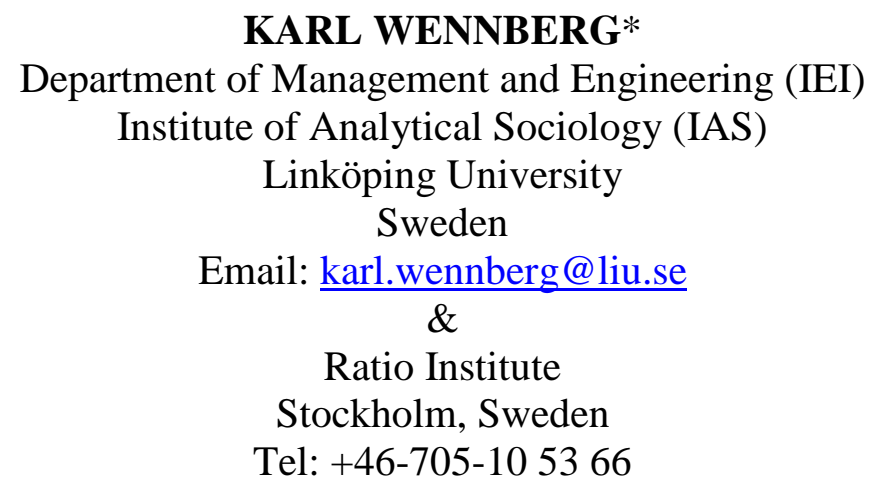

FRÉDÉRIC DELMAR

Sten K. Johnson Centre for Entrepreneurship

School of Economics and Management, Lund University

P.O. Box 7080

S-220 07 Lund

Sweden

E-mail: Frederic.Delmar@fek.lu.se

\author{
ALEXANDER MCKELVIE \\ Department of Entrepreneurship \& Emerging Enterprises \\ Whitman School of Management \\ Syracuse University \\ 721 University Ave. \\ Syracuse, NY 13244 \\ USA \\ E-mail: mckelvie@syr.edu
}

JEL Codes: L26, M13

Keyword: Growth, Survival, Aspiration levels, Focus of attention, New ventures, Risk preferences

Acknowledgments: We are indebted to Pär Åhlström, Marcus Asplund, Gaylen Chandler, Per Davidsson, Olof Ejermo, Tore Ellingsen, Stefan Jonsson, Daniel Halvarsson, Phil Kim, Lasse Lychnell, Jim March, Frida Pemer, Siri Terjesen, Johan Wiklund, Frederick Witte, Tiantian Yang, and seminar participants at the Stanford GSB Macro luncheons, CIRCLE at Lund University, Universidad Pablo de Olavide, and Uppsala University for helpful comments. Financial support from the Swedish Research Council (340-2013-5460) and Riksbankens Jubileumsfond (M12-0301:1).

*Corresponding author 
VARIABLE RISK PREFERENCES IN NEW VENTURE GROWTH AND SURVIVAL

\begin{abstract}
We outline and test a decision-making theory of new venture growth and survival. Building upon research in entrepreneurship and decision making under risk, we hypothesize that entrepreneurs' attention to survival and aspiration reference points changes based on venture age (experience-based learning), size (differences in decision complexity), and performance decision domain. Examining a panel of 14,760 new ventures in the professional services sector, our findings show how risk preferences change as a venture ages and increases in size. This approach offers a more nuanced view of decision making under risk and provides a theoretical explanation for the common patterns of new ventures' probability of exit and growth diminishing with age and size.
\end{abstract}

\title{
1. Executive Summary
}

We develop and test a model of how entrepreneurs make decisions under risk to explain when and how decisions related to venture exit and growth are made as new ventures evolve. Previous models of new venture growth and exit have tended to focus on differences between ventures, assume that ventures either grow or exit, or that venture growth and exit are triggered by aspirations or performance thresholds that differ between entrepreneurs. We address these gaps by conceptually and empirically linking venture growth and exit to each other and theorizing about the conditions in a venture's evolution where entrepreneurs will prefer growth or exit. Our approach thereby offers a more nuanced view of decision making under risk and provides a theoretical explanation for the common patterns of new ventures' probability of exit and growth diminishing with venture age and size.

Drawing upon theories of decision-making under uncertainty, we hypothesize how entrepreneurs' decisions to grow, exit or not change are based on their venture's age, its size, and the performance decision domain. We look at two performance decision domains: when the venture is facing threats to survival, and when it is performing close to the aspired performance level. Examining a panel of 14,760 new ventures in the professional services sector in Sweden, our findings show how risk preferences change as a venture ages and increases in size. 
We find that entrepreneurs whose ventures face threats to survival are more likely to seek growth to restore performance rather than to cut losses and terminate their ventures, especially as the venture ages. When the venture is larger and decision complexity increases, entrepreneurs are also less likely to terminate their ventures when facing threats to survival, but they will are less likely to seek growth to restore performance. Further, we find that when entrepreneurs operate relatively close to their aspired level of performance, they are less likely to choose growth the older the venture and when it is larger. Growth is a more common option when entrepreneurs perform below aspirations, especially as they age or manage larger, more complex ventures.

\section{Introduction}

While new venture growth and exit are important themes in the entrepreneurship literature, research about the decision making surrounding these issues remains sparse (Gilbert et al., 2006; Shepherd et al., 2015; Wright and Stigliani, 2013). Economics-inspired models of new venture growth and exit highlight that new ventures follow a "grow or exit" logic (Jovanovic, 1982; Pakes and Ericson, 1998). In these models, entrepreneurs are positioned as "rational" decision makers who, based on previous venture performance, choose to grow their firm if it performs well or to exit if it performs poorly. Such models fail to explain why most ventures never grow but still survive (Coad et al., 2013; Haltiwanger et al., 2012) and why the probability of new venture growth and exit seems to diminish with venture age and size (Bradley et al., 2011; Geroski et al., 2010). Models of growth and exit from social psychology highlight new ventures' decisions to grow or exit as being based not only on actual firm performance but also on firm-specific differences in performance thresholds and aspirations for growth (Baum and Locke, 2004; Gimeno et al., 1997; Wiklund et al., 2003). Such models do not account for how changes in thresholds and aspirations over time may affect growth or how past performance may influence future decision making. 
To address the shortcoming of prevailing models of new venture growth and exit, we outline a model of decision making under risk in new ventures derived from managerial decision theory and entrepreneurship research. Our model explains when and how decisions related to exit and growth are made as new ventures evolve. We build upon March and Shapira's (1992) theory of variable risk preferences, in which risk preferences shift relative to reference points rather than to an absolute value. Such risk preferences are reference dependent such that decisions are evaluated as either gains or losses relative to two repeatedly updated reference points—an aspiration reference point and a survival reference point. In these decisions, decision makers seek to minimize losses rather than maximize gains (Kahneman and Tversky, 1979; March and Shapira, 1987). In the context of new ventures, entrepreneurs' reactions to these two reference points can help explain decisions to exit, continue without changes in size, or grow as well as the ways these decisions might change throughout venture development.

We theorize about how these risk preferences change with increasing venture age and size approximating experience-based learning and differences in decision complexity (Le Mens et al., 2011) and across two decision domains: the domain of extreme losses and the domain of gains and losses. In the decision domain of extreme losses, we predict how entrepreneurs shift attention between the survival and aspiration reference points and how this affects their decision to exit, persist as is, or grow (Hu et al., 2011). The high likelihood of new venture exit makes the survival reference point especially appropriate in our model and underlines the distinctiveness of the new venture context for studying decision making. In the decision domain of losses and gains, we predict how performance relative only to the aspiration reference point affects decisions to persist or grow (Shimizu, 2007).

Our predictions are tested using detailed matched employee-employer data for 14,760 new ventures in the professional services industry. We follow these firms during their first 
eight years of existence or until they exited. While most of these firms were founded with fewer than two employees, some firms grew larger over time. We use survival models and fixed-effects panel models to test how entrepreneurs' attention to a survival reference point and a firm-specific aspiration point shapes the likelihood of exit or growth.

In doing so, we provide two contributions to research on new venture survival and growth. First, we contribute to research on the growth and survival of new ventures by offering a novel alternative to the rational decision-making models of new venture exit and growth, which do not consider experience-based learning (Coad et al., 2013; Pakes and Ericson, 1998) and decision complexity. Our model of variable risk preferences in entrepreneurial decision making relative to two distinct reference points extends the literature into a previously unexplored area. The theory explains the erratic patterns of new venture growth and survival (Coad et al., 2013; Delmar et al., 2003; Gilbert et al., 2006) by suggesting they are not "near random” and explaining the conditions under which new ventures might grow, exit, or maintain their same size.

Second, by examining decision making in two domains, we are able to provide novel insights into decision making under risk. In the domain of extreme losses, we extend March and Shapira's (1992) model of shift in reference point attention by adding new explanations for behavior in threatening situations, such as when exit is looming. We explain how entrepreneurs' shifts in attention depend on their venture’s age and size. This offers a novel explanation for when and under what conditions entrepreneurs' exit their ventures (Wennberg et al., 2010), what role multiple reference points play in decision making (March and Shapira 1992; Weber and Johnson 2009), and what competing views may exist regarding whether threats to survival lead to increased risk taking or to risk aversion and rigidity (Levinthal and March 1993). 
Further, in the decision domain of gains and losses, we argue and find that risk preferences vary with venture size and age. Our findings indicate that entrepreneurs in the youngest and smallest ventures elect to grow when performance is above the aspiration reference point, whereas entrepreneurs in comparably older or larger ventures prefer growth when performance is below the aspiration reference point. This finding highlights the importance of gains over losses in new entrepreneurs’ decision making (Shepherd et al., 2015) and also suggests that some of the conflicting evidence regarding the performance-growth relationship in firms (Audia and Greve, 2006; Miller and Chen, 2004) can be explained by contextual differences (e.g., firm size and age). This is important inasmuch as greater theoretical development is needed to explain differences and inconsistencies in new ventures' performance patterns compared to larger and established organizations (Bradley et al., 2011; Busenitz and Barney, 1997).

\section{Theory}

\subsection{A Decision-Making Theory of New Venture Survival and Growth}

Our theory adapts March and Shapira’s (1992) reference-dependent preferences model to provide a decision-making explanation for why new venture growth and exit vary with venture size and age. In their model, decision makers begin with a certain level of initial resources and go through a sequence of independent draws (i.e., performance feedback) that creates a history of cumulated or depleted resources, experience-based learning, and aspirations. Decision makers’ preferences for future options depend on performance history, level of resources, and the ways future options are framed (March and Shapira, 1987). In the context of entrepreneurs' decisions under risk, decisions to grow or exit are thus modeled as a function of the venture's decision complexity and of experience-based learning from performance feedback. Our focus is on entrepreneurs' allocation of attention to survival and aspiration reference points, which are known to differ in two decision domains: the domain of 
gains and losses and the domain of extreme losses (Tversky and Fox, 1995). We extend March and Shapira's work by showing that risk preferences in these two decision domains depends on the context of firms' experienced-based learning as they age (Le Mens et al., 2011) and size-based differences in decision complexity (Aldrich and Auster, 1986).

Reference-dependent preferences in new ventures. New ventures engage in the process of bringing their initial products/services to a market, forming customer and supplier bases, and establishing organizational processes and procedures (Delmar and Shane, 2004). New ventures' early development depends on decisions made under high levels of risk as they enter the market with limited resources to exploit a business opportunity (Shepherd et al., 2015). Early feedback on firm performance during these initial stages informs entrepreneurs about the productivity of their efforts and helps shape their performance aspirations (Cassar, 2010), thus impacting decisions about whether and how to persist with their venture or not. Our theory models entrepreneurs' decisions as being guided and adapted to their survival and aspiration reference points (March and Shapira, 1992), with three options of differing risk level related to venture growth: (1) exit; (2) persist without changes; or (3) engage in important organizational changes, such as employment growth.

In our theory, entrepreneurs evaluate options relative to two reference points and the risks involved relative to these reference points. Entrepreneurs’ perception of risks depends on whether options' are framed as gains or losses, with the baseline assumption that entrepreneurs similar to other decision makers seek to minimize losses rather than maximize gains (Kahneman and Tversky, 1979; Sarasvathy, 2001). Following prospect theory, the difference between financial gains and losses will lead to loss aversion such that affordable losses are a more important consideration than potential gains (Bazerman, 1984). This reasoning suggests that entrepreneurs will be risk seeking in situations of losses and risk averse in situations of gains. We extend this notion by considering two reference points in our 
study: the survival reference point and the aspiration reference point (March and Shapira, 1987, 1992). The survival reference point is the point at which performance is so low that it depletes resources to the extent that positive beliefs about future outcomes are eroded (Audia and Greve, 2006; Ocasio, 1995). This reference point is especially salient in the context of new ventures as they may be launched with limited resources and their performance potential is unknown ex ante (DeTienne, Shepherd and De Castro, 2008; Gruber, 2010). March and Shapira (1992) describe the aspiration reference point as an aspired level of performance by entrepreneurs relative to their current level of resources. Key to our theory is that entrepreneurs shift their attention between these reference points, and as a consequence, their preferences for risk as gains and losses are framed differently.

Following March and Shapira, the aspiration reference point most salient to our theory is the venture's historical aspirations as entrepreneurs learn from the experience accumulated in the venture over time. Repeatedly updated aspirations are important for new ventures because it is recent performance (albeit temporally limited) that offers insights into future prospects.

Decision domains. Our theory states the decision domain will determine entrepreneurs' risk preferences for an option to exit, pursue their venture at its current size, or grow. Decision domains affect how entrepreneurs frame their preferences (Payne and Bettman, 1992; Weber and Johnson, 2009), which means that taking risks when in the proximity of the aspiration reference point is different from taking risks when in a domain of extreme losses, where the venture is close to the survival reference point (March and Shapira, 1992).

Domain of extreme losses. The domain of extreme losses arises when the venture is close to its survival point and most of its resources are depleted. When close to the survival point, entrepreneurs will focus their attention on either the aspiration reference or survival 
point. A focus on the aspiration point will lead entrepreneurs to increase risk taking and seek growth in order to improve their performance (Miller and Chen, 2004; Wiseman and Bromiley, 1996). However, if focus shifts to the survival reference point, entrepreneurs will be risk averse and instead be more likely to exit or continue their operations as is (Audia and Greve, 2006; Desai, 2008; Miller and Chen, 2004).

Domain of gains and losses. The domain of gains and losses is the second decision domain in our theory. In this context, entrepreneurs operate relatively close to their aspired level of performance. Gains or losses relative to the aspired performance level do not threaten survival in the short term (Greve, 2003b). In this domain, entrepreneurs' aspirations adapt to prior losses and gains, and they consider future options as either gains or losses.

Context dependence. Our theory depicts entrepreneurs' attention to either the survival or aspiration reference point as being context dependent, specifically as related to venture age and size. In terms of age, newer ventures differ from more established firms because they are in a cognitively challenging situation in which entrepreneurs need to rapidly learn through experience how to serve markets and develop knowledge of how to transform resources into demanded services (Gruber et al., 2012), to find routines to standardize production and knowledge transfer, and to deal with the uncertainty related to their ability (Wu and Knott, 2006). As ventures age, cognitive demands are reduced as ventures can rely on established routines and accumulated knowledge of how to produce better services and products (Majumdar, 2004; Naldi and Davidsson, 2014). The establishment of routines as ventures age thus enhances entrepreneurs' satisfaction with the current situation of their venture. Moreover, such routines and knowledge become increasingly difficult to reallocate. In terms of size, smaller ventures are characterized by simple decision-making structures that often rely on a sole decision maker or a few decision makers easily acquiring and implementing new information. With increasing venture size, the decision-making 
structure becomes more complex, with groups, political factions, and accountability affecting decision making, for example, by ignoring new information (Cyert and March, 1963; Klotz et al., 2013). Additionally, with increasing size comes growing specialization, thereby increasing trust and coordination costs among members (Heavey and Simsek, 2015). Firm size and age are thus distinct context dependencies for attention to the survival or aspiration reference points, which we argue will impact entrepreneurs' risk preferences and attention to reference points.

In the domain of extreme losses, entrepreneurs' attention will change with venture age and size due to different reactions to a losing course of action, which in turn depends on their accumulated commitment (Sleesman et al., 2012) and the size of the venture (March and Shapira, 1992). Escalation of commitment is the tendency for decision makers to maintain commitment to losing courses of action, even when facing negative feedback. This commitment is stronger as ventures age since resources and routines becomes increasingly firm specific and therefore difficult to relocate and change (Staw and Hoang, 1995). Escalation is also more likely with increasing venture size as decision environments become more complex. With increasing decision complexity, entrepreneurs are less likely to admit failure to organizational members and more likely to ignore outside options and information challenging the status quo (McCarthy et al., 1993; Sleesman et al., 2012; Tversky and Fox, 1995).

In the domain of gains and losses, aspiration points and managerial preferences often change with venture age and size (Greve, 2003b). Initial performance based on prior losses and gains will induce entrepreneurs to adjust both their aspiration reference point and preferences to take risks (Weber and Johnson, 2009). However, as new ventures age, entrepreneurs' willingness to adapt aspirations fades, and they will be more likely to seek growth to restore performance when it falls below the aspiration level (Greve, 2008). With 
increasing size, entrepreneurs are less likely to seek additional growth since satisfying behavior is intimately related to larger size and organizational structures are more difficult to change (Cyert and March, 1963).

Three strategic options. Our theory of new venture growth and survival is built on three options that entrepreneurs face during the early stages of new ventures: to exit, to continue without changes in size, or to grow their venture. Each option comes with risk defined as whether or not the outcomes are predictable or whether there is a substantial variance in outcomes. However, entrepreneurs’ preferences for these options will shift depending on venture context and decision domains. Further, preferences for an option are likely to vary when (1) outcomes are unknown ex ante, (2) outcomes could potentially be positive or negative, and (3) entrepreneurs' emotional ambivalence is high (Payne and Bettman, 1992). These factors are highly salient in the decision-making environment of new ventures.

The first option is venture exit. Entrepreneurs may be at risk of either terminating their venture too early and foregoing the possibility of realizing the potential of their investment or terminating too late and not recouping the time and funds invested (DeTienne, Shepherd and De Castro, 2008; O'Brien et al., 2003). The outcome of this option is predictable and final as the venture would no longer operate. Hence, exit is an option with a comparatively low risk.

The second option is to continue operations without change, which could have both negative and positive outcomes. Negative outcomes include failing to adapt to changing environments (Levinthal and March, 1993) or remaining at a sub-optimal size and missing out on new profitable opportunities. Positive outcomes are maintained strategic flexibility (Wiklund et al., 2003), limited further investment, and the autonomy that comes from limited hierarchy and low coordination costs. To continue without changing size represents a low to moderate risk option since no changes represent a status quo with relatively known outcomes. 
The third option is to seek growing the venture. Employment growth is different from sales growth since the latter is to a larger degree a performance outcome (Chandler et al., 2009). Rather, employment growth in a new venture is associated with changes in organizational structure and operations (Penrose, 1959). The venture develops from a simple to a more complex organization in which entrepreneurs have to implement new routines and control systems. Employment growth is the option with the highest level of risk for, and outcomes may be both positive and negative (Bromiley, 2010). Negative outcomes include costs of hiring and firing due to search, training, and monitoring costs (Mishina et al., 2004). Growth may also be emotionally costly to entrepreneurs as it limits flexibility and places professional demands over personal goals. Increased performance from growth is uncertain and may take time to realize, and the probability of short-term venture exit increases (Delmar et al., 2013). Positive outcomes from new venture growth include increased resource buffers against competitive threats and the signaling of greater legitimacy and success (Bradley et al., 2011), which may increase long-term survival (Penrose, 1959). Growth is a high-risk option because outcomes are highly variable and can be both positive and negative.

Following prospect theory, our theory builds upon the idea that framing the situation as a loss or gain will alter preferences for different strategic options even though the underlying objective risk remains the same. The option with the lowest risk is exit, followed by pursuing without changes in size. The option of growth has the highest relative risk and variance in outcomes. Preferences for any of these options, and hence risk taking, will shift across domains and contexts. This provides a 2 x 2 framework, with predictions about decision making in two decision domains moderated by two contextual variables, as summarized in Table 1.

Table 1: Focus of Attention and Variable Risk Preferences in New Ventures

\begin{tabular}{|l|l|l|}
\hline & Domain of extreme losses & Domain of gains and losses \\
\hline Age & $\begin{array}{l}\text { (1) When close to the survival reference point, } \\
\text { younger ventures are more likely to exit }\end{array}$ & $\begin{array}{l}\text { (2) Younger ventures are more likely to grow } \\
\text { when above the aspiration reference point }\end{array}$ \\
\hline
\end{tabular}




\begin{tabular}{|c|c|c|}
\hline & $\begin{array}{l}\text { (Hypothesis 1a), but older ventures are more } \\
\text { likely to grow (Hypothesis 1b). } \\
\text { Logic: Entrepreneurs escalate their commitment } \\
\text { over time because venture-specific resources } \\
\text { and routines have developed that are difficult to } \\
\text { reallocate. }\end{array}$ & $\begin{array}{l}\text { (Hypothesis 3a), but older ventures are more } \\
\text { likely to grow when below the aspiration } \\
\text { reference point (Hypothesis 3b). } \\
\text { Logic: Entrepreneurs react strongly to initial } \\
\text { streaks of positive or negative feedback, } \\
\text { producing an early imprinting adaptation. } \\
\text { Adaptation flattens out as "safe" payoffs are } \\
\text { obtained. }\end{array}$ \\
\hline Size & $\begin{array}{l}\text { (3) When close to the survival reference point, } \\
\text { smaller ventures are more likely to exit } \\
\text { (Hypothesis 2a), but larger ventures are more } \\
\text { likely to grow (Hypothesis 2b). } \\
\text { Logic: Entrepreneurs in larger ventures escalate } \\
\text { their commitment because they are more prone } \\
\text { to disregard new information than individuals } \\
\text { and are less willing to consider outside options } \\
\text { as they are mutually committed to the group. }\end{array}$ & $\begin{array}{l}\text { (4) Small ventures are more likely to grow when } \\
\text { above the aspiration reference point (Hypothesis } \\
\text { 4a), but larger ventures are more likely to grow } \\
\text { when below the aspiration reference point } \\
\text { (Hypothesis 4b). } \\
\text { Logic: Entrepreneurs will initiate changes only } \\
\text { when performing below historical aspirations } \\
\text { because larger organizational structures and more } \\
\text { decision processes limit change. }\end{array}$ \\
\hline
\end{tabular}

\section{Hypothesis Development}

\subsection{Extreme Losses and Decisions to Grow or Exit}

Venture age. A first tenet in our theory is that decision making in new ventures is different than that in established ventures since the former will be more attentive to the survival point whereas the latter will be more attentive to the aspiration point when facing financial distress (Wiklund et al., 2010). New ventures are different from established firms because they lack firm-specific resources, routines, and operations experience (Desai, 2008). As new ventures age, they learn through experience to transform generic resources into venture-specific resources and services, such as technologies, networks, and routines (Gruber, 2010). While gaining experience tends to lower the likelihood of exit by improving the efficient use of resources and increased knowledge, such venture-specific resources and knowledge are increasingly difficult to reallocate to other types of operations. Allocation and transformation are done through “experiential search,” whereby knowledge proven to be useful from experience is retained through routines and practices (Greve, 2003b). Due to these differences, entrepreneurs will be more attentive to the survival point as their ventures have yet to develop venture-specific routines and resources, and entrepreneurs can still consider outside options for paid employment if their venture does not perform satisfactorily (Gimeno 
et al., 1997). Such outside options diminish the probability of escalation of commitment and decrease risk taking (Whyte, 1993).

Conversely, entrepreneurs whose ventures have aged more will be increasingly attentive to the aspiration point because they have created resources and routines that are difficult to reallocate elsewhere. In this context, low performance might be caused by insufficient adaptation to a changing environment, and experience-based learning might lock the venture into previously successful strategies (Lant and Mezias, 1992; Toft-Kehler et al. 2014). Entrenchment and attachment to their venture may make entrepreneurs more likely to escalate their commitment when facing feedback that could endanger their venture's existence (Staw, 1976). If their venture performs poorly after a period of successful adaptation, entrepreneurs find themselves in the domain of losses, which our theoretical model suggests would lead to increased risk taking. Similar patterns can be found in LeMens et al.’s (2011) study of American breweries and brewpubs between 1961 and 1997, for which early performance had a crucial long-term impact on new venture survival. In another study by DeTienne, Shepherd, and De Castro (2008) of 171 underperforming high-tech firms, new ventures were found to be more likely to persist if they had previously experienced positive performance. History of operations thus seems to be an important contextual determinant of reactions to survival-threatening performance. Accordingly, we hypothesize that entrepreneurs whose ventures have aged are more likely to seek the risky option of growth to restore performance:

Hypothesis 1a: Younger ventures are more likely than older ventures to exit when close to the survival reference point.

Hypothesis 1b: Older ventures are more likely than younger ventures to grow when close to the survival reference point.

Firm size. Our second prediction in the domain of extreme losses focuses on entrepreneurs' reactions to survival threats (Audia and Greve, 2006; Miller and Chen, 2004). 
Moreover, there are important contextual determinants to escalation of commitment (Sleesman et al., 2012). When facing financial distress, individual decision making is different from decision making in groups and larger organizations (Klotz et al., 2013). In very small firms, entrepreneurs only answer to themselves and seldom to other organizational members, such as employees or other entrepreneurs. The decision to exit is therefore personal and easier to accept (DeTienne, Shepherd and DeCastro, 2008). With increasing size, ventures’ decision-making structure becomes more complex, raising the risk of escalation of commitment (Cyert and March, 1963; Klotz et al., 2013). With increasing venture size, entrepreneurs' initial decisions to seek growth or merely continue operations at the same scale become more visible. This visibility decreases entrepreneurs' willingness to admit failure to employees and stakeholders. Thus, running larger firms may make entrepreneurs more likely to escalate commitment. For example, such patterns have been found in McCarthy et al.’s (1993) study on 1,112 small US firms between 1985 and 1987, which argues that escalation of commitment regarding re-investment decisions is likely to occur in the face of negative market feedback. In a study of much larger Japanese shipbuilding firms with 589 to 78,104 employees, Audia and Greve (2006) find that managers of smaller firms are more likely to focus on their survival point and reduce risk taking when facing negative performance. They also find that managers of larger firms more often focus on their aspirational point and increase risk taking when facing negative performance. Our theoretical arguments and some prior studies thus support the somewhat counterintuitive prediction that increasing firm size may lead entrepreneurs to disregard the option of exit even when facing negative performance, instead opting for the more risky option of growth (see also Holland and Shepherd, 2013). Therefore, we hypothesize the following:

Hypothesis 2a: Smaller ventures are more likely than larger ventures to exit when close to the survival reference point. 
Hypothesis 2b: Larger ventures are more likely than smaller ventures to grow when close to the survival reference point.

\subsection{Gains and Losses and Decisions to Seek Growth or Exit}

Venture age. The second part of our theory consists of younger ventures' reacting differently to changes in performance relative to the aspiration point. New ventures exhibit uncertainty around ability and market potential, and their performance history is limited (Wu and Knott, 2006). As such, entrepreneurs will be especially attentive to emerging trends in performance as they try to learn from past performance and determine risk surrounding expected performance levels and their ability to manage resources. The development of performance history induces behavioral changes as aspirations are updated based on previous outcomes (Denrell, 2007; Lant and Mezias, 1992). Willingness to adapt their aspirations tends to decrease as firms age because further learning and aspiration adaptation is cognitively demanding. This leads entrepreneurs to become increasingly satisfied with current performance and less likely to explore alternative strategic options.

New venture performance and decisions have imprinting effects such that ventures with positive performance are likely to continue to do well over time (Le Mens et al., 2011; Mathias et al., 2015), especially related to growth (Bamford et al., 2004). In a study of 500 new banks established in the United States between 1985 and 1998, Bamford et al. (2004) find that initial conditions in terms of resources and management choices had significant effects on growth five years after founding. This gives some support for our theoretical suggestion that early positive performance increases aspiration levels by enhancing entrepreneurs’ beliefs about demand for their product or service and their own abilities, encouraging them to adjust aspiration levels upward and increase risk taking toward growth. Similarly, we expect a negative downward effect such that beliefs in their abilities and aspirations gradually erode if performance falls below their aspiration levels. 
As new ventures age, however, entrepreneurs will be increasingly unwilling to change their aspirations over time due to “satisficing” behavior (Denrell, 2007; Greve, 2003b). Satisfactory performance is likely to lead entrepreneurs to adhere to "safe" decisions with known and positive past payoffs and avoid decisions with unknown outcomes or those that may lead to negative outcomes. This suggests the probability of new ventures’ preferring growth when performing above historical aspirations should decrease as the venture ages. However, if performance falls below their aspiration point, entrepreneurs in older ventures will be more likely to initiate risky strategic options, preferring growth to restore performance to a satisfactory level. Thus, we propose the following:

Hypothesis 3a: Younger ventures are more likely than older ventures to grow when above the aspiration reference point.

Hypothesis $3 \boldsymbol{b}$ : Older ventures are more likely than younger ventures to grow when below the aspiration reference point.

Firm size. The final part of our theory centers on the development of organizational structure and predicts that entrepreneurs with smaller ventures react differently to changes in performance than entrepreneurs with larger ventures. With larger size, structures and organizational complexity increase as entrepreneurs have to share information, define roles, and negotiate changes. A cornerstone in Cyert and March’s (1963, pp. 30-51) behavioral theory of the firm is that in larger firms, changes are difficult to initiate and implement, and entrepreneurs will do so only if performance falls below their aspiration reference point. In larger firms, goals, aspirations, and changes are the outcome of a process in which different coalitions bargain to reach consensus. This more complex decision context increases risk aversion, making entrepreneurs "satisfied" when performance is above their aspiration reference point. For example, investigating 11 large Japanese shipbuilding firms between 1971 and 1996, Greve (2003) finds that high performance reduces risk taking (as measured by research and development investment and innovation launches). Our final hypotheses suggest 
that the probability of new entrepreneurs' having growth preferences should decrease for larger ventures that perform above their aspiration point. However, if performance is below the aspiration point, entrepreneurs of larger ventures will be more likely to act in a riskseeking manner by choosing growth as a way to restore performance. This leads to our final hypotheses:

Hypothesis 4a: Smaller ventures are more likely to grow than larger ventures when above the aspiration reference point.

Hypothesis $4 \boldsymbol{4 b}$ : Larger ventures are more likely to grow than smaller ventures when below the aspiration reference point.

\section{Data and Methods}

We analyze the full population of new incorporated ventures with one or more employees in the Swedish professional services sector from 1995 to 2002, encompassing 14,760 new ventures. Examples of the professional services prevalent in the data are accounting, law, management and technology consulting, and advertising. The panel of firms was assembled by Statistics Sweden, the country’s official Bureau of Census. The Swedish tax authorities provided reliable accounting data, which are necessary to test models of performance feedback but are normally difficult to find for privately held firms. In Sweden, incorporated firms were required by law to have an auditor until 2010, which makes for more reliable accounting data (Bradley et al., 2011). The required capital of 100,000 SEK (approximately $\$ 14,000$ ) for incorporating a firm also helps us eliminate hobby or part-time ventures.

A new venture is defined as an independent new legal entity not in existence in prior years. Statistics Sweden assigns all legal entities a unique identifier, which we use to ensure that all firms were independent in the year of entry and not a subsidiary of other firms, thereby avoiding problems with changes in firm name or legal form. These requirements allow us to identify genuinely new independent ventures in a robust way. 
We test our theory on new ventures in the professional service sector for three reasons. First, this sector comprises a significant and growing proportion of all new firms, both in terms of number of entries and of growth firms (Delmar et al., 2011; Haltiwanger et al., 2012). This offers important empirical extensions as extant studies of performance feedback have focused mainly on large established firms in capital-intensive industries, such as railroads (Desai, 2008), shipbuilding (Audia and Greve, 2006), and manufacturing (Miller and Chen, 2004), or on large service ventures, such as radio broadcasting (Greve, 1998) or insurance (Greve, 2008). For example, Audia and Greve (2006) investigate the moderating effect of size for aspiration performance and investments among firms having 589 to 78,104 employees. Desai (2008) examines railroad firms where the log mean number of employees was 8.95, suggesting the mean size of firms was approximately 7,700. Further, the mean age of the firms was 103 years. Greve (2008) reports the mean age of his sample of insurance firms to be 37 years. These samples are in stark contrast to our sample of new and independent ventures. Second, our indicator of growth (number of employees) and performance (sales per employee) are standard metrics in industries that rely on skilled personnel and low assets (Greenwood et al., 2005; Hitt et al., 2001). Third, by studying the population of new ventures over time in one specific industry sector, we reduce a primary source of heterogeneity among new ventures.

\subsection{Modeling Firm Exit and Growth}

We use two outcome variables: exit and growth. The need to consider both exit and growth simultaneously is central to our theory since the decision to grow depends on the decision to not exit (Gilbert et al., 2006). Methodologically, both outcomes are important to consider since there is the potential for bias with truncated samples due to higher performance variance among surviving ventures. In our study, 7,147 (48.42\%) ventures exited during the period of observation. Only including surviving ventures would bias the coefficients 
downward with a significant effect on both exit and growth in regressions predicting growth. We correct for this by using a survival-correction variable when modeling growth. The survival function is also used to test our hypotheses about the survival reference point.

Firm exit and selection. We use Cox’s semi-parametric survival regression to model venture exit. The Cox model does not necessitate assumptions regarding the shape of the hazard rate and has been used previously in research on decision making in contexts of extreme losses (Shimizu, 2007). We use this model to construct our survival bias correction based on a generalized Heckman's procedure to create the selection-correction variable “Lambda” (e.g. Delmar and Shane, 2003; Toft-Kehler et al., 2014). A good selection correction should contain at least one variable that predicts exit but not growth. In our model, this variable is the number of entrants in the five-digit industry, a theoretically strong indicator of industry attractiveness exogenous to the focal venture (Barron et al., 1994).

Firm growth model. We define growth as the ratio between next-period and currentperiod size and firm growth rate as the ratio minus one (Greve, 2008). This specification relies on Gibrat's law of size-independent growth, which assumes that ventures have the same growth rates independent of size and is defined as follows:

$$
\mathrm{S}_{\mathrm{t}+1} / \mathrm{S}_{\mathrm{t}}=\mathrm{S}_{\mathrm{y}}^{\mathrm{t}} \exp \left(\beta \mathrm{X}_{\mathrm{t}}+\varepsilon\right)
$$

The left-side expression $S_{t+1} / S_{t}$ denotes the growth rate, and $S$ denotes size. The rightside expression factor $S_{y}^{t}$ is multiplied with a set of covariates $X_{t}$ with coefficients $\beta$ and an error term $\varepsilon$. This is made into a linear model by taking the log of both sides and is extended with a coefficient $\gamma$, which permits growth to be size dependent. The resulting model explains the log of size at time $t+1$ as a linear function of the covariates and the log of size at time $t$. 
All models are estimated with fixed effects, which accounts for changes over time and parcels out the unexplained variance as an error component, leading to the final equation:

$$
\mathrm{LN}\left(\mathrm{S}_{\mathrm{it}+1}\right)=(1+\gamma) \mathrm{LN}\left(\mathrm{S}_{\mathrm{it}}\right)+\beta \mathrm{X}_{\mathrm{it}}+v_{i}+v_{t}+\varepsilon_{i t}
$$

$X_{i t}$ represents time-variant covariates for firm $i$ at time $t, v_{i}$ is the fixed effect of firm $i$, $v_{t}$ is the effect of time periods, and $\varepsilon_{i t}$ represents unobserved variance. $\mathrm{LN}$ is the natural logarithm. Fixed firm effects control for omitted variables that differ between firms and are constant over time, such as heterogeneity in risk propensity (Hu et al., 2011).

\subsection{Dependent Variables}

Exit. We define exit as the complete cessation the venture as an independent unit, coded as 1 in the year when a venture exits. Otherwise, this variable is coded as 0 . Ventures still active by the end of our eight-year observation period are right censored. Statistics Sweden tracks three forms of exit: closure, split, and merger. Closure is most prevalent (93.13\%), meaning that the venture and its establishment(s) cease to exist and all employees leave. Because selling or merging the venture may be seen as a successful outcome, we exclude ventures that were acquired or merged from our analysis and treat these ventures as censored (Gimeno et al., 1997).

Firm growth. We capture growth as the change in number of employees because it is a highly discretionary management decision, which is necessary to test our theory. We provide the growth measurement above. Employment growth is different from sales growth, which is often a response to market demand and does not necessarily lead to structural change in a venture (Chandler et al., 2009). We are interested in organizational changes that involve risk. Employment is a relevant indicator because it is the way most ventures in the professional services context increase long-term productivity (Greenwood et al., 2005; Hitt et 
al., 2001). The organizational efforts to integrate new employees are often substantial. Given the human capital-intensive nature of such ventures, we believe our measure has high external validity.

\subsection{Independent Variables}

Survival reference point. To separate ventures for which performance falls slightly below their aspiration point and ventures for which performance falls so low that it puts their survival at risk, we rely on Altman's Z-score model of financial distress, which is frequently used in research on organizational behavior (e.g., Miller and Chen, 2004), including research on new ventures in Sweden (Bradley et al., 2011). The model uses indicators of size, leverage, liquidity, and performance based on Altman's (1968) optimization of the model's predictive abilities as Z-score $=\mathrm{A} * 3.3+\mathrm{B} * 0.99+\mathrm{C} * 0.6+\mathrm{D} * 1.2+\mathrm{E} * 1.4$. A equals earnings before interest and taxes divided by total assets, which measures productivity of assets; B represents net sales/total assets, a standard ratio illustrating the sales-generating ability of assets; C represents book value of equity/total liabilities, which shows how much assets can decline in value before the liabilities exceed the assets and the venture becomes insolvent; $\mathrm{D}$ represents working capital/total assets, which measures net liquid assets relative to total capitalization; and E reflects retained earnings/total assets, measuring the amount of reinvested earnings and/or losses. Ventures with Z-scores below 1.8 are generally considered “near bankruptcy.” Following our theoretical discussion of the survival reference point as a dichotomous outcome, we code the survival reference point as 1 for all ventures with Z-scores below 1.8 and 0 otherwise, which also eases interpretation when investigating interactions. The results section reports the robustness test when alternating the Z-score threshold.

Performance aspiration point. We use sales per employee as our performance measure and the basis for our aspiration point variable. This measure is widely accepted as the most important performance measure in professional services ventures, which are labor and 
skill intensive. The ability to sell a maximum number of billable hours per employee is a strong indicator of performance. This performance metric is related to the question of whether or not an entrepreneur should hire another employee (i.e., grow) since higher average sales per employee imply an ability to sustain profitability when more employees are hired (Arora and Nandkumar, 2011). We thus believe our performance indicator has strong external and internal validity. Following March and Shapira (1987, 1992), the aspiration reference point salient to our theory is historical aspiration, calculated as a moving two-year average of a venture’s past performance (Lant and Mezias, 1992; Levinthal and March, 1981).

Performance history thus starts at Year 2 in a venture's evolution. Weighing the most recent year's performance as double to that of the earlier year's performance does not affect the significance level or direction of the effects obtained.

Performance above or below firms' social aspirations. We calculate this control variable as the difference between the focal venture's performance and the average performance of all other firms in the same industry at the five-digit Industrial Classification level (the most detailed breakdown available, which is equivalent to the six-digit level of the North American Industry Classification System). Our aspiration point variables are entered as spline functions, meaning that separate variables are entered for performance above or below a firm-specific aspiration point (Greve, 2003b). This approach allows the variables to have different effects above or below the aspiration point. The variables above the aspiration point range from 0 to positive values. The variables below the aspiration point range from negative values to 0 .

Moderator variables. We test our interaction hypotheses related to venture age and size in addition to the direct effects of historical aspirations. Age is measured as the number of years from inception. Size is measured as the log of employees in each year. Both are non-centered 
to ease interpretation of interactions. To mitigate simultaneity problems, we lag all predictor variables one year.

\subsection{Control Variables}

To account for the fact that entrepreneurs’ perceived risk level related to the options of growing, exiting, or pursuing operations may depend on their venture’s resource stock and current industry conditions, we control for time-variant factors at the firm and industry levels and also include fixed firm effects to account for firm-specific differences in risk perception. First, we control for slack resources using two variables. We do this because slack is known to affect growth and performance (George, 2005; Greve, 2003a). To measure absorbed slack, we use the log of yearly investments made (Audia and Greve, 2006). Yearly investment corresponds to all investments made in building, land, and machinery. To measure unabsorbed slack, which corresponds to excess and immediately available resources, we use operating cash flow (Singh, 1986). Second, to ensure our findings are not affected by returns on prior investments, we include a control for return on assets (ROA) (Desai, 2008; Greve, 2003a), despite ROA being a less reliable performance variable for new and small ventures due to tax incentives to not generate profits. Third, we control for differences in size and growth rates across industry sub-sectors using control variables measuring number of entries (Geroski et al., 2010), mean sales, sales growth (Van de Ven et al., 1984), and number of patents (Klepper and Sleeper, 2005). All industry controls are time variant and measured at the five-digit industry level. We therefore provide strong controls for differences between and within the industries over time.

\section{Results}

\subsection{Descriptives: Firm Exit and Growth Rates}

Table 2 shows the development of new ventures in the Swedish business services sector. All cohorts are included in the first row of Table 2, so the number of ventures is 
affected by attrition and right censoring of the cohorts at different ages depending on when they enter. Out of 14,760 new ventures entering the industry, 7,147 (48.42\%) exited during the period of observation, and the average survival time was only 2.64 years. This finding reinforces the idea that taking into account exit is vital for effectively explaining the performance of professional services ventures. Table 2 also reveals that the growth of the average venture is low, but the standard deviation for growth increases rapidly over time. A substantial number of ventures remains during their first eight years of existence, whereas growing ventures differ increasingly from the non-growing ventures. After eight years of existence, $6.2 \%$ of the remaining ventures account for $53.1 \%$ of all employees. This indicates high-growth non-linearities. 
Table 2. Evolution of the Population between 1994 and 2002-All Cohorts

\begin{tabular}{|c|c|c|c|c|c|c|c|c|}
\hline Venture age: & 1 & 2 & 3 & 4 & 5 & 6 & 7 & 8 \\
\hline Number of ventures in the industry (all cohorts) & 14,760 & 9,119 & 5,995 & 4,025 & 2,728 & 1,829 & 1,026 & 408 \\
\hline Mean survival rate for all cohorts (\%) & $100.00 \%$ & $70.82 \%$ & $55.91 \%$ & $46.28 \%$ & $38.67 \%$ & $33.32 \%$ & $27.93 \%$ & $22.65 \%$ \\
\hline Mean exit rate for all cohorts (\%) & & $29.18 \%$ & $21.35 \%$ & $17.31 \%$ & $15.79 \%$ & $13.39 \%$ & $12.36 \%$ & $11.30 \%$ \\
\hline Mean size for new ventures & 2.84 & 3.41 & 3.83 & 4.11 & 4.17 & 4.84 & 6.07 & 8.82 \\
\hline Std. dev. (size in employees) for new ventures & 7.80 & 11.04 & 15.16 & 22.28 & 18.28 & 40.33 & 62.14 & 84.91 \\
\hline Sum of employees in all new ventures & 41,969 & 31,085 & 22,988 & 16,546 & 11,364 & 8,851 & 6,229 & 3,599 \\
\hline Mean sales/empl. (1,000s SEK) & 989 & 1,117 & 1,112 & 1,196 & 1,152 & 1,117 & 1,093 & 1,001 \\
\hline Std. dev. (sales/empl.) & 3,221 & 3,579 & 1,908 & 2,277 & 1,868 & 1,342 & 1,686 & 1,050 \\
\hline
\end{tabular}

Notes: Sales per employee is inflation adjusted. The currency conversion rate during the period was 1 USD $=9.5$ SEK on average. "New ventures" indicate that the measures concern only our population of new ventures. "Industry" indicates that the measures concerns all ventures present in the industry. $\mathrm{N}=39,890$.

\section{Table 3. Descriptive Statistics and Correlation Matrix}

\begin{tabular}{|c|c|c|c|c|c|c|c|c|c|c|c|c|c|c|c|c|c|c|c|c|c|c|}
\hline & & Mean & Std. Dev. & Min & Max & 1 & 2 & 3 & 4 & 5 & 6 & 7 & 8 & 9 & 10 & 11 & 12 & 13 & 14 & 15 & 16 & 17 \\
\hline 1 & Employee growth (LN) & 0.80 & 0.80 & 0.00 & 7.49 & & & & & & & & & & & & & & & & & \\
\hline 2 & Performance $<$ historical asp. & -1.05 & 3.13 & -22.30 & 0.00 & 0.03 & & & & & & & & & & & & & & & & \\
\hline 3 & Performance > historical asp. & 1.50 & 4.00 & 0.00 & 28.52 & -0.01 & 0.13 & & & & & & & & & & & & & & & \\
\hline 4 & Performance < social asp. & -4.21 & 4.09 & -19.45 & 0.00 & -0.01 & -0.02 & 0.26 & & & & & & & & & & & & & & \\
\hline 5 & Performance > social asp. & 2.88 & 8.81 & 0.00 & 60.92 & -0.01 & -0.10 & 0.50 & 0.34 & & & & & & & & & & & & & \\
\hline 6 & Lambda & 0.91 & 0.61 & 0.00 & 4.31 & -0.15 & -0.20 & 0.17 & -0.16 & 0.07 & & & & & & & & & & & & \\
\hline 7 & Survival point & 0.22 & 0.42 & 0.00 & 1.00 & 0.10 & 0.00 & -0.07 & -0.23 & -0.08 & 0.56 & & & & & & & & & & & \\
\hline 8 & ROA (LN) & 0.10 & 0.12 & 0.00 & 2.84 & -0.02 & 0.08 & 0.04 & 0.23 & 0.07 & -0.31 & -0.34 & & & & & & & & & & \\
\hline 9 & Operating cash flow & $5,1+\mathrm{E} 4$ & $1,64+\mathrm{E} 6$ & $-1,1+E 7$ & $6,83+\mathrm{E} 6$ & -0.03 & 0.03 & 0.04 & 0.16 & 0.09 & -0.08 & -0.13 & 0.21 & & & & & & & & & \\
\hline 10 & Firm investments (LN) & 7.16 & 5.22 & 0.00 & 20.45 & 0.18 & 0.02 & 0.03 & 0.14 & 0.05 & -0.38 & -0.03 & 0.06 & -0.05 & & & & & & & & \\
\hline 11 & Age & 2.81 & 1.79 & 1.00 & 8.00 & -0.08 & -0.19 & 0.13 & 0.07 & 0.01 & -0.27 & -0.13 & -0.10 & 0.00 & -0.02 & & & & & & & \\
\hline 12 & Firm size (LN employees) & 0.58 & 0.84 & 0.00 & 7.49 & 0.58 & -0.04 & -0.02 & -0.11 & -0.06 & -0.39 & 0.00 & -0.10 & -0.08 & 0.21 & 0.10 & & & & & & \\
\hline 13 & Firm patents & 0.00 & 0.03 & 0.00 & 2.00 & 0.01 & -0.01 & 0.02 & -0.02 & 0.01 & 0.05 & 0.02 & -0.02 & -0.02 & 0.00 & -0.01 & 0.00 & & & & & \\
\hline 14 & Industry sales growth & $4,4+\mathrm{E} 4$ & $5,19+E 4$ & $-2,75+\mathrm{E} 5$ & $5,57+\mathrm{E} 5$ & 0.08 & 0.03 & -0.03 & 0.01 & -0.01 & 0.39 & 0.07 & 0.03 & 0.01 & 0.02 & -0.08 & -0.08 & -0.01 & & & & \\
\hline 15 & Sum entrants in industry & 0.09 & 0.05 & 0.00 & 0.17 & -0.06 & -0.03 & 0.00 & -0.04 & -0.01 & 0.02 & 0.01 & 0.05 & 0.02 & 0.00 & 0.00 & -0.10 & 0.00 & 0.53 & & & \\
\hline 16 & Sum patents in industry & 0.01 & 0.04 & 0.00 & 0.25 & 0.05 & -0.02 & 0.02 & -0.20 & -0.01 & -0.10 & 0.07 & -0.01 & -0.03 & -0.01 & 0.05 & -0.01 & 0.00 & 0.22 & 0.31 & & \\
\hline 17 & Mean sales in industry & 81.08 & 104.54 & 15.33 & 2116.56 & 0.04 & -0.01 & 0.03 & -0.32 & -0.01 & -0.05 & 0.05 & -0.07 & -0.07 & 0.00 & 0.03 & 0.13 & 0.01 & -0.05 & -0.13 & 0.23 & \\
\hline
\end{tabular}

Notes: $\mathrm{N}=39,890$. Natural logarithm (LN). Industry sales growth and industry mean sales are measured in billions of SEK. Correlations above 0.01 are significant at $\mathrm{p}<0.05$ (two-sided Pearson correlations). 
Means, standard deviations, and correlations are presented in Table 3. The majority of correlations among the variables are low to moderate, but some correlations exceed 0.50, notably among the variables for aspiration points, between size and growth, and between industry entry rates and growth rates. These correlations increase the probability that Type I errors (i.e., not finding a relationship when there is one) and significance levels will be underestimated.

\subsection{Multivariate Analysis of Firm Exit and Growth}

We use a hierarchical approach to check for consistency across models, introducing the independent variables in steps. We first interpret the results for Hypotheses $1 \mathrm{a}$ and $1 \mathrm{~b}$ and then for Hypotheses 2a and 2b concerning our predictions for decisions in the domain of extreme losses. We then discuss Hypotheses 3a and 3b followed by Hypotheses 4a and 4b concerning our predictions for decision in the domain of gains and losses.

To test the interaction hypotheses, we plot the marginal coefficients with 95\% confidence intervals. The premise of this is that the effect of our two independent variables (survival point or aspiration point) on our two dependent variables (survival and employment growth) might vary with venture age and size. Our hypotheses predict that venture age and size will moderate the effects of performance relative to one of the two reference points (aspiration and survival) for new ventures’ employment growth and survival.

Equations with moderators need to be interpreted with care. If we simply look at the coefficients for these interaction terms, inference may be erroneous since coefficients show estimates of 'average effects' when venture age $=0$ or venture size $=0$. This is not practically relevant for the firms in our study, since the youngest age age of firms is 1 and only a relatively small share of firms have an (LN) employment size equal to 0 . One must also take care to not examine separate $t$ statistics when testing a joint hypothesis. It is problematic to conclude that $\mathrm{H}_{0}$ 
is rejected based on the coefficients of the independent and moderator variables being different from zero and the statistical significance of the $t$ statistic since the joint effect of these variables is not assessed (Davidson et al., 1981). Moreover, interpretations of individual coefficients are insufficient to assess the presence of a moderator effect when variance differs across values (Brambor et al., 2006). We therefore follow the recommendations in the literature on interaction effects to estimate the partial effect of the survival point and the aspiration point on (LN) employment growth and survival at relevant value for venture age and size with confidence intervals (Wooldridge, 2002).

To formally test for such a moderation effect, we include only constitutive terms and then calculate marginal effects and standard errors for these terms. We then test the significance of the effect at each point in each venture's early development (i.e., at Age 1, 2, 3, 4, 5, 6, 7, and 8) and firm size. This allows us to investigate when and where entrepreneurs’ preferences change, conditional on size and age. To establish if the different point estimates are significantly different from zero and from each other, as is suggested by our theory, we examine the possible overlap of the confidence intervals. To do that, we plot the marginal effects for the domain of extreme losses in Figure 1 and for the domain of gains and losses in Figure 2.

Table 4 presents hazard rates from the Cox regression models predicting venture exit. Model 1 shows the full model without the interaction effects ( $\mathrm{Chi}^{2}$ 1530.26), Model 2 adds the interaction for venture age $\left(\Delta \mathrm{Chi}^{2} 5.85 ; \mathrm{p}<0.05\right)$, and Model 3 adds the interaction effect for size ( $\left.\Delta \mathrm{Chi}^{2} 2.52 ; \mathrm{n} . \mathrm{s}.\right)$. Firm size and industry growth are the strongest predictors of exit among the control variables. Similar to previous studies, new ventures' age and size are negatively related to the likelihood of exit (Baum et al., 2001; Geroski et al., 2010). Model 1 in Table 4 shows that the probability of exit diminishes with increasing age $(0.93, \mathrm{p}<0.001)$ and size $(0.79 ; \mathrm{p}<0.001)$. 
Table 5 presents the fixed-effects panel models predicting growth. Model 1 shows the full model without the interaction effects, Models 2 and 3 add the interactions for the survival point with venture age and size, respectively. Models 4 and 5 add the interactions for the performance below and above the historical aspiration point with venture age and size, respectively. Explanatory power $\left(\mathrm{R}^{2}\right)$ ranges from 0.31 (Model 1) to 0.32 (Model 5). The increased power is statistically significant but relatively weak $\left(\Delta \mathrm{R}^{2}\right.$ of 0.06$)$. Similar to what we found in the model on new venture exit (Table 4), Model 1 in Table 5 shows that new ventures' probability of growth diminishes with age $(-0.24, \mathrm{p}<0.001)$ and size $(-0.11 ; \mathrm{p}<0.001)$. The control variable for unabsorbed slack (Operating cash-flow) is not statistically significant. The control variable for absorbed slack (LN Venture investment) is significant but negative (-0.03; $\mathrm{p}>0.001)$. Taken together this indicates that results are not driven by access to excess resources or liquidity constraints not captured by our survival point. The survival correction variable Lambda is significant in all models, indicating the salience of controlling for survival bias.

\subsection{Decisions in the Domain of Extreme Losses: Shifts in Reference Points}

Hypothesis 1a predicts that younger ventures are more likely to exit when close to the survival point, investigated in Model 2 of Table 4 and in the upper-left quadrant of Figure 1. The direct effect of the survival reference point is positive and significant in Table 4, showing an increased probability of exit $(1.46 ; \mathrm{p}<0.001)$. While the hazard rate for the interaction between age and survival reference point is positive and significant in Table 4 (1.04; $\mathrm{p}<0.05)$, Figure 1 shows the marginal effects for survival point times age to have overlapping confidence intervals, thus rejecting Hypothesis 1a. Even in the presence of a statistically significant moderator estimated at all variables' mean values (the 1.04 interaction hazard rate between age and the survival reference point) we see a trivial and non-significant effect across the range of venture age in years when plotting the results. 
Table 4. Cox Regression Predicting Exit, Hazard Rates

\begin{tabular}{|c|c|c|c|}
\hline VARIABLES & Model 1 & Model 2 & Model 3 \\
\hline \multirow[t]{2}{*}{ H1a: Survival point * age } & & $1.04 *$ & \\
\hline & & $(0.02)$ & \\
\hline \multirow[t]{2}{*}{ H2a: Survival point * size } & & & 0.94 \\
\hline & & & $(0.03)$ \\
\hline \multirow[t]{2}{*}{ Performance $<$ historical asp. } & $0.95^{* * *}$ & $0.95^{* * *}$ & $0.95 * * *$ \\
\hline & $(0.00)$ & $(0.00)$ & $(0.00)$ \\
\hline \multirow[t]{2}{*}{ Performance > historical asp. } & $1.05^{* * *}$ & $1.05^{* * *}$ & $1.05^{* * *}$ \\
\hline & $(0.00)$ & $(0.00)$ & $(0.00)$ \\
\hline \multirow[t]{2}{*}{ Performance < social asp. } & $0.98 * * *$ & $0.98^{* * *}$ & $0.98 * * *$ \\
\hline & $(0.00)$ & $(0.00)$ & $(0.00)$ \\
\hline \multirow[t]{2}{*}{ Performance > social asp. } & $1.00+$ & 1.00 & 1.00 \\
\hline & $(0.00)$ & $(0.00)$ & $(0.00)$ \\
\hline \multirow[t]{2}{*}{ Survival point } & $1.59 * * *$ & $1.46^{* * *}$ & $1.63 * * *$ \\
\hline & $(0.05)$ & $(0.07)$ & $(0.06)$ \\
\hline \multirow[t]{2}{*}{ ROA (LN) } & $0.49 * * *$ & $0.48^{* * *}$ & $0.50 * * *$ \\
\hline & $(0.06)$ & $(0.06)$ & $(0.06)$ \\
\hline \multirow[t]{2}{*}{ Operating cash flow } & 1.00 & $1.00+$ & 1.00 \\
\hline & $(0.00)$ & $(0.00)$ & $(0.00)$ \\
\hline \multirow[t]{2}{*}{ Firm investments (LN) } & $0.97 * * *$ & $0.97 * * *$ & $0.97 * * *$ \\
\hline & $(0.00)$ & $(0.00)$ & $(0.00)$ \\
\hline \multirow[t]{2}{*}{ Venture age } & $0.93^{* * *}$ & $0.92 * * *$ & $0.93^{* * *}$ \\
\hline & $(0.01)$ & $(0.01)$ & $(0.01)$ \\
\hline \multirow[t]{2}{*}{ Firm size (LN employees) } & $0.79 * * *$ & $0.79 * * *$ & $0.80^{* * *}$ \\
\hline & $(0.01)$ & $(0.01)$ & $(0.02)$ \\
\hline \multirow[t]{2}{*}{ Firm patents } & 1.68 & 1.67 & 1.67 \\
\hline & $(0.57)$ & $(0.57)$ & $(0.57)$ \\
\hline \multirow[t]{2}{*}{ Industry sales growth } & $1.00 * * *$ & $1.00^{* * *}$ & $1.00^{* * *}$ \\
\hline & $(0.00)$ & $(0.00)$ & $(0.00)$ \\
\hline \multirow[t]{2}{*}{ Sum of entrants in industry } & $0.11^{* * *}$ & $0.10^{* * *}$ & $0.11^{* * *}$ \\
\hline & $(0.03)$ & $(0.03)$ & $(0.03)$ \\
\hline \multirow[t]{2}{*}{ Sum of patents in industry } & $0.09 * * *$ & $0.09^{* * *}$ & $0.09 * * *$ \\
\hline & $(0.03)$ & $(0.03)$ & $(0.03)$ \\
\hline \multirow[t]{2}{*}{ Mean sales in industry } & $1.00 * * *$ & $1.00^{* * *}$ & $1.00 * * *$ \\
\hline & $(0.00)$ & $(0.00)$ & $(0.00)$ \\
\hline Firm-year observations & 39,890 & 39,890 & 39,890 \\
\hline Log-likelihood value & -65587.13 & -65585.87 & -65584.21 \\
\hline Chi $^{2}$ test statistic & $1530.26 * * *$ & $1536.11^{* * *}$ & $1532.78^{* * *}$ \\
\hline$\Delta \mathrm{Chi}^{2}$ (compared to Model 1) & $\mathrm{n} / \mathrm{a}$ & $5.85 *$ & 2.52 \\
\hline
\end{tabular}

Notes: Coefficients with Huber-White standard errors in parentheses. Venture-year observations $=39,890$. Unique ventures $=14,760$. Exits $=7,147 .{ }^{* * *} \mathrm{p}<0.001,{ }^{* *} \mathrm{p}<0.01,+\mathrm{p}<0.10$. The same variable is used to calculate the survival correction variable Lambda. 
Hypothesis $1 \mathrm{~b}$ predicts that older ventures will be more likely to grow when close to the survival point. This hypothesis is investigated in Model 2 of Table 5 and in the upper-right quadrant of Figure 1. The direct effect of our survival reference point is positive and significant $(0.65 ; \mathrm{p}<0.001)$, suggesting an average effect of ventures' pursuing growth when close to this reference point (Audia and Greve, 2006; Miller and Chen, 2004; Wiseman and Bromiley, 1996). The interaction between age and the survival reference point is positive and significant $(0.07 ; \mathrm{p}<$ 0.001). Figure 1 shows plotted marginal effects for the impact of the survival reference point conditional on venture age for growth. The marginal effect in employment growth when a venture is close to the survival point increases linearly from 0.70 in Year 1 to 1.24 in Year 8 with confidence intervals being different from age 1 starting at age 5 , thus supporting Hypothesis $1 \mathrm{~b}$.

Hypothesis 2a predicts that smaller ventures are more likely to exit when close to the survival point. This hypothesis is investigated in Model 3 of Table 4 and in the bottom-left quadrant of Figure 1. We test Hypothesis 2a by plotting the marginal effects of the hazard rate for the interaction between size and the survival reference point for exit. While the hazard rate of the interaction between the survival point and size is not statistically significant (0.94), Figure 1 shows that the marginal effects of being close to the survival reference point attenuate with changes in size. Being close to the survival point increases the likelihood of exit by $35 \%$ for ventures with only three employees (LN 0.1) but only by $17 \%$ for ventures with 20 or more employees (LN 3), which supports Hypothesis 2a. Even in the presence of a statistically nonsignificant moderator estimated at all variables' mean values (the 0.94 interaction coefficient between size and survival reference point) we thus see positive and non-trivial results across the firm-size range when plotting the results in the figure.

Hypothesis $2 \mathrm{~b}$ predicts that larger ventures are more likely to grow when close to the survival point and is investigated in Model 3 of Table 5 and in the bottom-right quadrant of 
Figure 1 . The direct effect of being close to the survival reference point is positive $(0.70 ; \mathrm{p}<$ 0.001), and the interaction term is significant $(0.06$; $\mathrm{p}<0.05)$. However, Figure 1 shows that the marginal effect of proximity to the survival point on growth at various sizes is small with overlapping confidence intervals, thus rejecting Hypothesis 2b. Similar to the test for Hypothesis 1a, we see that even in the presence of a statistically significant moderator estimated at all variables' mean values (the 0.06 interaction coefficient between size and survival reference point) we see a trivial and non-significant effect across the range of venture age in years when plotting the results. 
Table 5. Fixed-Effects Panel Models Predicting Employee Growth

\begin{tabular}{|c|c|c|c|c|c|}
\hline VARIABLES & Model 1 & Model 2 & Model 3 & Model 4 & Model 5 \\
\hline \multirow[t]{2}{*}{ H1b:Survival point * age } & & $0.07^{* * *}$ & & & \\
\hline & & $(0.01)$ & & & \\
\hline \multirow[t]{2}{*}{ H2b:Survival point * size } & & & $0.06 *$ & & \\
\hline & & & $(0.03)$ & & \\
\hline \multirow[t]{2}{*}{ H3a: Performance > historical asp. * age } & & & & $-0.01 * * *$ & \\
\hline & & & & $(0.00)$ & \\
\hline \multirow[t]{2}{*}{ H3b: Performance < historical asp. * age } & & & & $0.01^{* * *}$ & \\
\hline & & & & $(0.00)$ & \\
\hline \multirow[t]{2}{*}{ H4a: Performance $>$ historical asp. ${ }^{*}$ size } & & & & & $-0.02 * * *$ \\
\hline & & & & & $(0.00)$ \\
\hline \multirow[t]{2}{*}{ H4b: Performance < historical asp. * size } & & & & & $0.03^{* * *}$ \\
\hline & & & & & $(0.00)$ \\
\hline \multirow[t]{2}{*}{ Lambda } & $-0.99 * * *$ & $-1.03 * * *$ & $-0.90 * * *$ & $-0.96 * * *$ & $-1.10 * * *$ \\
\hline & $(0.08)$ & $(0.08)$ & $(0.09)$ & $(0.09)$ & $(0.09)$ \\
\hline \multirow[t]{2}{*}{ Performance $<$ historical asp. } & $-0.06 * * *$ & $-0.06 * * *$ & $-0.05 * * *$ & $-0.10 * * *$ & $-0.08 * * *$ \\
\hline & $(0.01)$ & $(0.01)$ & $(0.01)$ & $(0.01)$ & $(0.01)$ \\
\hline \multirow[t]{2}{*}{ Performance $>$ historical asp. } & $0.05^{* * *}$ & $0.06^{* * *}$ & $0.05^{* * *}$ & $0.08^{* * *}$ & $0.07 * * *$ \\
\hline & $(0.01)$ & $(0.01)$ & $(0.01)$ & $(0.01)$ & $(0.01)$ \\
\hline \multirow[t]{2}{*}{ Performance < social asp. } & $-0.03 * * *$ & $-0.03 * * *$ & $-0.02 * * *$ & $-0.03 * * *$ & $-0.03 * * *$ \\
\hline & $(0.00)$ & $(0.00)$ & $(0.00)$ & $(0.00)$ & $(0.00)$ \\
\hline \multirow[t]{2}{*}{ Performance > social asp. } & $-0.00 * *$ & $-0.00 * *$ & $-0.00 * *$ & -0.00 & $-0.00 * * *$ \\
\hline & $(0.00)$ & $(0.00)$ & $(0.00)$ & $(0.00)$ & $(0.00)$ \\
\hline \multirow[t]{2}{*}{ Survival point } & $0.80^{* * *}$ & $0.65^{* * *}$ & $0.70^{* * *}$ & $0.78^{* * *}$ & $0.87^{* * *}$ \\
\hline & $(0.05)$ & $(0.05)$ & $(0.06)$ & $(0.06)$ & $(0.06)$ \\
\hline \multirow[t]{2}{*}{ ROA (LN) } & $-0.51 * * *$ & $-0.54 * * *$ & $-0.45 * * *$ & $-0.47 * * *$ & $-0.58 * * *$ \\
\hline & $(0.08)$ & $(0.08)$ & $(0.08)$ & $(0.08)$ & $(0.08)$ \\
\hline \multirow[t]{2}{*}{ Operating cash flow } & -0.00 & -0.00 & -0.00 & -0.00 & -0.00 \\
\hline & $(0.00)$ & $(0.00)$ & $(0.00)$ & $(0.00)$ & $(0.00)$ \\
\hline \multirow[t]{2}{*}{ Venture investments (LN) } & $-0.03 * * *$ & $-0.03 * * *$ & $-0.03 * * *$ & $-0.03 * * *$ & $-0.03 * * *$ \\
\hline & $(0.00)$ & $(0.00)$ & $(0.00)$ & $(0.00)$ & $(0.00)$ \\
\hline \multirow[t]{2}{*}{ Venture age } & $-0.24 * * *$ & $-0.26 * * *$ & $-0.24 * * *$ & $-0.21 * * *$ & $-0.26 * * *$ \\
\hline & $(0.01)$ & $(0.01)$ & $(0.01)$ & $(0.01)$ & $(0.01)$ \\
\hline \multirow[t]{2}{*}{ Venture size (LN Employees) } & $-0.11 * * *$ & $-0.11 * * *$ & $-0.10 * * *$ & $-0.11 * * *$ & $-0.07 *$ \\
\hline & $(0.03)$ & $(0.03)$ & $(0.03)$ & $(0.03)$ & $(0.03)$ \\
\hline \multirow[t]{2}{*}{ Venture patents } & $0.800^{* * *}$ & $0.81^{* * *}$ & $0.75^{* * *}$ & $0.73^{* * *}$ & $0.81^{* * *}$ \\
\hline & $(0.17)$ & $(0.17)$ & $(0.18)$ & $(0.17)$ & $(0.17)$ \\
\hline \multirow[t]{2}{*}{ Industry sales growth } & $0.00^{* * *}$ & $0.00^{* * *}$ & $0.00^{* * *}$ & $0.00^{* * *}$ & $0.00^{* * *}$ \\
\hline & $(0.00)$ & $(0.00)$ & $(0.00)$ & $(0.00)$ & $(0.00)$ \\
\hline \multirow[t]{2}{*}{ Sum of entrants in industry } & 0.300 & 0.19 & 0.52 & 0.43 & 0.04 \\
\hline & $(0.46)$ & $(0.45)$ & $(0.467$ & $(0.46)$ & $(0.47)$ \\
\hline \multirow[t]{2}{*}{ Sum of patents in industry } & $-0.89 * *$ & $-0.96 * * *$ & $-0.66^{*}$ & $-0.77 * *$ & $-1.200 * * *$ \\
\hline & $(0.28)$ & $(0.27)$ & $(0.29)$ & $(0.28)$ & $(0.30)$ \\
\hline \multirow[t]{2}{*}{ Mean sales in industry } & $-0.00 * *$ & $-0.00 * *$ & $-0.00 *$ & $-0.00 *$ & $-0.00 * *$ \\
\hline & $(0.00)$ & $(0.00)$ & $(0.00)$ & $(0.00)$ & $(0.00)$ \\
\hline Constant & $1.98^{* * *}$ & $2.05^{* * *}$ & $1.88^{* * *}$ & $1.86^{* * *}$ & $2.09 * * *$ \\
\hline & $(0.11)$ & $(0.11)$ & $(0.12)$ & $(0.11)$ & $(0.12)$ \\
\hline Firm-year observations & 39,890 & 39,890 & 39,890 & 39,890 & 39,890 \\
\hline R-squared & 0.31 & 0.32 & 0.32 & 0.31 & 0.32 \\
\hline
\end{tabular}

Notes: Venture-year observations $=39,890$. Unique ventures $=14,760$. Huber-White standard errors are in parentheses. ${ }^{* * *} \mathrm{p}<0.001,{ }^{* *} \mathrm{p}<0.01,{ }^{*} \mathrm{p}<0.05$. We control for interactions between social aspirations and size/age. 
- INSERT FIGURE 1 HERE - SEE SEPARATE ATTACHMENT -

- INSERT FIGURE 2 HERE - SEE SEPARATE ATTACHMENT -

\subsection{Decisions in the Domain of Gains and Losses: Adapting Aspirations and Firm Growth}

In this section, we test how venture age and size moderate risk taking above and below the aspiration point. Hypothesis 3a predicts that younger ventures are more likely to grow when above the aspiration reference point. This hypothesis is investigated in Model 4 of Table 5 and in the upper-left quadrant of Figure 2. We find the direct coefficient for aspirations above historical performance to be significant and positive $(0.08$; $\mathrm{p}<0.001)$, indicating that an increasing performance trend will increase risk propensity toward growth. The interaction coefficient in Model 4 of Table 5 between performance above the historical aspiration and age is negative and significant $(-0.01 ; \mathrm{p}<0.001)$. Figure 2 displays the marginal effect of performance above historical performance conditional on venture age on growth. We see that younger ventures are risk seeking toward growth, an effect that decreases with age, where confidence intervals no longer overlap at age 4 compared to age 1 , to become close to zero at age 8,. Hypothesis 3a is thus supported.

Hypothesis 3b predicts older ventures to be more likely to grow when below the aspiration reference point. This hypothesis is investigated in Model 4 of Table 5 and in the upperright quadrant of Figure 2 based on new ventures' performance trends. The direct effects show a 
negative coefficient for performance below historical aspirations $(-0.10 ; \mathrm{p}<0.001)$, which is further moderated by venture age as indicated by the positive interaction term $(0.01 ; \mathrm{p}<0.001)$. Figure 2 displays plotted marginal effects of performance below historical aspiration as a function of age. Interestingly, we see that early negative performance lowers risk propensity toward growth with confidence intervals no longer overlapping at age 4 compared to age 1 Only in Year 8 is the marginal effect above 0, and negative performance increases risk propensity toward growth, as expected. This supports Hypothesis 3b.

Hypotheses 4a and 4b follow the same structure as Hypotheses 3a and 3b but focus on venture size. Hypothesis 4a argues that smaller ventures are more likely to grow when performing above the aspiration reference point. This is investigated in Model 5 of Table 5 and in the bottom-left quadrant of Figure 2. The interaction coefficient with size is negative $(-0.02$; $\mathrm{p}<$ 0.001), and the plotted marginal effects in Figure 2 show that performance above the aspiration reference point has a stronger effect on growth for smaller ventures. This reveals smaller ventures to be most risk seeking toward growth, an effect that diminishes with increasing size up until there is no effect of performance feedback on growth, which occurs when ventures have more than 33 employees (LN 3.5). This supports Hypothesis 4a.

Hypothesis 4b predicts larger ventures to be more likely to grow than smaller ventures when below the aspiration reference point. Model 5 of Table 5 shows a negative direct effect of performance below the aspiration reference point $(-0.08 ; \mathrm{p}<.001)$, with the interaction effect being significant and positive $(0.03 ; \mathrm{p}<.001)$. The bottom-right quadrant of Figure 2 presents the marginal effect, which reveals smaller ventures to be more risk averse toward growth when experiencing a negative performance trend, which provides support for Hypothesis 4b. A shift from being risk averse to risk seeking seems to occur when the firm has around 20 employees (LN 3.0). The confidence intervals for risk taking toward growth are not significantly different 
from 0 until the new venture's size is 55 employees (LN 4.0), after which new ventures become more risk seeking toward growth when experiencing a negative performance trend.

\subsection{Robustness Checks}

We conduct several robustness tests. Hausman tests support the use of fixed-effect models over random effects despite cross-sectional variance in the models. Multicollinearity checks for each interaction and the survival correction variable (Lambda) reveal stable condition indexes across various specifications when introducing the interaction effects, but Lambda showed condition values between 49.57 and 52.47. While this may inflate the coefficients and standard errors, indications of multicollinearity in interaction models do not render our inferences invalid (Berry et al., 2012). ${ }^{1}$ The survival correction variable is theoretically motivated (Wright and Stigliani, 2013). Post-hoc analyses indicate that 5,829 (82\%) of exiting ventures were liquidated while 1,318 (18\%) were taken over by other firms. Excluding those firms taken over by other ventures does not change our main results. Since Cox regression may be sensitive to tied events, we also test our survival models using Weibull, Breslow, exponential, and logit distributions, all of which have results (available upon request) similar to the Cox model when predicting exit. We also test alternating the threshold value for the dichotomous survival reference point based on the financial distress variable (Z-score) between 2.90 and 1.60, which does not significantly affect the results. Because venture size in employees is highly correlated to our dependent variable of

\footnotetext{
${ }^{1}$ We do not include year dummies as they are collinear with cohort dummies. Instead, we include a range of timevariant and theoretically motivated industry-level controls to account for changes across sectors and time. As these may fail to capture the effect of sudden shocks, we re-estimate the models using year dummies. Estimated marginal effects (i.e., our tests of all hypotheses) do not change except for Hypothesis $1 \mathrm{~b}$, which is no longer significant when we include the year dummy 2002. This dummy is negatively correlated to both survival and growth, potentially as a result of the economic downturn in 2002. Thus, although our overall theory receives support, the framing effects predicted in Hypothesis $1 \mathrm{~b}$ are not evident in this year of a severe economic downturn, suggesting that this finding may be limited to more normal economic conditions.
} 
employment growth $(r=.58)$, we re-run our analyses using venture size as sales instead. The results are largely unchanged. ${ }^{2}$

Finally, we investigate problems of reverse causality in two sets of robustness analyses ${ }^{2}$. We first re-estimate our survival models including lagged employment growth as a predictor to see if growth might drive ventures closer to bankruptcy. Our results do not change. Second, we re-estimate the growth models using a system GMM estimator with lagged dependent and independent variables to investigate whether some broader recursive cycle of causation may influence risk taking toward growth. Two-year lags were not significant or weaker in magnitude compared to one-year lags, indicating that our results are indeed driven by entrepreneurs’ reactions to performance in the preceding year (March and Shapira, 1987). The lagged dependent variable is not significant in the GMM model, indicating low risk of reverse causality.

\section{Discussion}

This paper provides a comprehensive theory explaining new venture growth and exit as a function of entrepreneurial decision making under risk. We propose an alternative to standard decision models based on expected utility theories of new venture growth and exit and focus on growth and exit as a process of experienced-based learning and decision complexity for which changes in entrepreneurial risk taking are a function of an interacting series of changes within the venture accompanied by changes in the characteristics of the growing venture (Penrose, 1959). Our theory explains when and how decisions related to exit and growth are made as new ventures evolve as a function of entrepreneurs’ variable risk preferences. Entrepreneurial preferences to grow or exit a new venture are judgments based on the actual performance of the firm relative to aspirations, resource levels, and the willingness to minimize losses rather than maximize gains.

\footnotetext{
${ }^{2}$ Results of all of the robustness tests are available upon request.
} 
Specifically, entrepreneurs' decisions to exit, to continue without changes in size, or to grow their venture stem from decision processes triggered by reactions to performance relative to two distinct reference points: the aspiration point and the survival point. We theorize and show that risky decisions in relation to these reference points are moderated by venture age (a proxy for experiential-based learning) and size (a proxy for decision complexity). These decisions are important in the new venture context as they face a high likelihood of exit and decision outcomes are highly uncertain (Shepherd et al., 2015). Our integrated framework helps explain why growth and exit rates diminish with venture age and size, which is a recurring theme in the entrepreneurship literature (Coad et al., 2013; Wright and Stigliani, 2013). Hence, we respond to recent literature reviews that have noted a dearth of studies accounting for decision making related to growth and explaining how growth is contingent on survival (e.g. Gilbert et al., 2006).

First, our analyses provide several nuanced findings concerning entrepreneurs’ focus of attention between the survival point and the aspiration point and the ways this focus affects risk preferences. The first part of our theory concerns the decision domain of extreme losses, wherein entrepreneurs' shift in focus of attention from a survival reference point to an aspiration reference point is conditioned by new ventures' having reached a certain age (experience-based learning) or size (decision complexity). We find that attention to the survival reference point is moderated by decision complexity (Hypothesis 2a) but not experience-based learning (Hypothesis 1a). Further, entrepreneurs' focus on the aspiration reference point is moderated by experience-based learning (Hypothesis 1b) but not by decision complexity (Hypothesis 2b). These findings suggest that the debate regarding the relationship between survival-threatening low performance and risk taking (e.g., Audia and Greve, 2006; Miller and Chen, 2004) may be informed by considering two separate decisions: (1) the decision to continue or exit and (2) the decision to grow or not (Greve, 2008). 
The second part of our theory concerns decisions in the domain of gains and losses (Hypotheses 3 and 4) and how attention to the aspiration reference point affects risk propensity in new ventures conditional on experience and decision complexity. We find support for our predictions that while an increasing performance trend will increase risk preferences toward growth, this effect is negatively moderated by variance in the different decision context of ventures' age and size. The experience-based learning following repeated decisions as new ventures age, together with increasing decision complexity of running larger ventures, leads entrepreneurs to react differently than originally predicted in the March-Shapira model of decisions under risk.

In a nutshell, we find that when facing survival threats and with increasing experience, entrepreneurs are not more likely to terminate their ventures. Instead they are more likely to choose growth. Similarly, with increasing decision complexity, entrepreneurs are not more likely to choose growth, but they are increasingly less likely to terminate their ventures. When entrepreneurs operate relatively close to their aspired level of performance, they are less likely to choose growth when performing above their aspirations as they gain experience or manage larger, more complex ventures. Similarly, they are more likely to choose growth when performing below their aspirations as they gain experience or manage larger, more complex ventures.

\subsection{Contribution to Research on New Venture Growth and Survival}

Our findings offer new insights for the diverse literature on new venture growth and survival, which most often represents separate streams of research and has been strongly based on an assumption of rational entrepreneurs. First, a majority of studies on new ventures explain growth and exit as between-firm differences rather than examine changes in the growth rates of individual firms over time (Coad et al., 2013; Geroski et al., 2010). This paper sketch a theory 
where growth and exit are simultaneously modeled as a process of organizational development where an interacting series of changes within the venture leads to increases in size accompanied by changes in the characteristics of the growing venture (Penrose, 1959). Juxtaposing insights from prospect theory and the behavioral theory of the firm, we develop predictions of how entrepreneurs will behave concerning venture growth and exit and how this behavior might change over time and with venture size (Shepherd et al., 2015). Our integrated framework helps explain why growth rates and exit rates diminish with venture age and size, which is a recurring theme in the entrepreneurship literature (Coad et al., 2013; Wright and Stigliani, 2013).

Second, by defining boundary conditions based on how new ventures' age and size affect risk preferences for exit or growth, we shed light on the puzzle related to the erratic patterns of new venture growth (e.g., Delmar et al., 2003; Shepherd and Wiklund, 2009). Our theoretical reasoning and empirical results explaining growth and exit as a function of decision making allows us to explain when ventures exit, when growth starts and stops, and why growth is triggered. The dual focus on exit and growth in our theory is important as the decision to grow is dependent on the decision to exit. Such a dual dependency helps to create links between growth and emerging themes in the entrepreneurship literature, such as studies that begin to address why some underperforming firms persist (DeTienne, Shepherd and De Castro, 2008).

Third, we contribute to the literature that discusses the role of financial performance and new venture growth (Davidsson et al., 2009; Jovanovic, 1982; Pakes and Ericson, 1998). Extant research on the relationship between growth and profitability remains mixed and rarely links these relationships to decision making under risk. Research on larger incumbent firms (Greve, 2003b, 2008) suggests that growth is primarily a reaction to negative performance feedback, with risks taken to restore-rather than to improve-performance. We provide a joint theoretical framework explaining why and when new ventures are likely to be risk averse or risk seeking 
depending on attention to the reference points of survival or aspiration. In doing so, we incorporate a more dynamic view of new venture growth as a process with performance feedback in which explanatory factors vary with age and size. The performance-feedback perspective helps overcome static models of new ventures that tend to adopt a linear approach to understanding growth trends over time rather than considering the naturally occurring ups and downs. Indeed, dynamic models that account for annual changes may allow scholars to overcome the limited explanatory power that currently plague growth models (McKelvie and Wiklund, 2010; Shepherd and Wiklund, 2009).

\subsection{Contribution to Decision Making in New Ventures}

Our theory and results highlight the unique context of selective attention to the survival and aspiration reference points in new venture growth and exit (Greve, 2008). The context of new ventures is unique as no performance history exists, entrepreneurs learn through experience, and there is a high degree of individual volition in decision making, which contrasts the "dominant coalitions” often found in large firms. Our study thus helps assess the contextual validity of behavioral decision theory in firms (Shinkle, 2012).

Combining these factors in the context of new ventures provides two novel contributions. First, in the decision domain of extreme losses, we predict and find support for a relationship between entrepreneurs' attention to either the survival reference point or the aspiration reference point and venture growth, effects which are contingent on ventures' age and size. This suggests a potential resolution to the long-standing discussion on whether entrepreneurs take greater risk or become inertial when facing threats to survival (Holland and Shepherd, 2013; Levinthal and March, 1993). Our decision-making theory of new venture development explains growth or exit as a result of selective attention to one of two reference points. With increasing size, entrepreneurs focus less on their survival point and the potential of exit but not increasingly on 
their aspiration point and the risky option of growth. With increasing age, entrepreneurs seem to focus increasingly on the aspiration performance point. Our analysis indicates this pattern only holds if they decide to continue with the venture as the focus on the survival point is not moderated by age. Thus, entrepreneurs seem to be especially attentive to emerging trends in performance rather than staying focused on original goals (Hu et al., 2011; Kazanjian and Drazin, 1990). While younger ventures are most likely to cut their losses and exit, we find that those who choose to persist are more likely seek growth in order to restore performance. These findings have implications for models of entrepreneurial persistence (DeTienne et al., 2008) and studies about entrepreneurs’ willingness to update goals and aspirations over time (Hu et al., 2011; LeMens et al., 2011). Our finding that age does not moderate this relationship might be due to many new ventures’ never being able cumulate enough resources to change focus from the survival point to the aspiration level. If so, most entrepreneurs would primarily be concerned with ensuring survival rather than seeking growth, which is in line with theories of decision framing and escalation of commitment in more or less complex decision-making contexts (Sleesman et al., 2012; Tversky and Fox, 1995).

Second, our paper provides evidence of the boundary conditions of performance feedback theory (Shinkle, 2012). We theorize and show that when in the domain of gains and losses, entrepreneurs in very small and relatively new ventures exhibit different risk preferences concerning decisions related to growth and exit compared to entrepreneurs in older and larger ventures (Audia and Greve, 2006; Desai, 2008). While positive feedback seems to increase risk preferences toward growth, negative performance feedback, in contrast, seems to diminish risk taking. This highlights the importance of historical dependence of aspirations and aspiration levels in explaining changes in risk preferences (March and Shapira, 1992, p. 177) and provides novel evidence that new ventures’ early development shapes the boundary conditions of 
performance feedback theory in that aspirations tend to "flatten out” with age as satisfactory performance is obtained (Denrell, 2007; Greve, 2003a). With increasing size, entrepreneurs act more risk averse unless performance falls below their aspiration level (Bamford et al. 2004), highlighting the risks of generalizing theories derived from samples of large established organizations to the domain of new ventures.

\subsection{Limitations and Future Research}

Our study also comes with limitations, several of which suggest interesting avenues for future research. An obvious limitation is that similar to other studies using secondary longitudinal data, we are not able to study entrepreneurs’ actual decisions, only decision conditions and outcomes at the firm level. Our approach is focused on firm-level factors rather than individuallevel factors. Future studies of individual factors that could affect risk taking or growth aspirations, such as risk propensity (Baron, 1998) or manager age (Levesque and Minniti, 2006), might add a further level of detail.

Another limitation is our use of venture age and size. Our theory is based on the assumption that entrepreneurs’ decision making under risk will change as a function of venture age and size. We use age as a proxy for experience-based learning and size as a proxy for decision-making complexity. However, age and size can proxy for a number of other mechanisms that we cannot fully rule out with the current design. Venture age may act as a proxy for factors distinct from experience-based learning but still related to decision making, such as legitimacy (Zimmerman and Zeitz, 2002) or the ability to adapt to environmental shifts without learning, especially if shocks are random (Frankish et al., 2012). New venture size may act as a proxy for factors distinct from decision complexity, such as hierarchical structure and degree of specialization (Sorensen, 2007). As such, our reliance on proxies could allow for alternate explanations-although our theory does not assume the presence of learning in the sense that 
managers become better in what they are doing (Coad et al., 2012). From a performance feedback perspective, learning is one potential outcome of managerial reactions to past performance (Levinthal and March, 1993). For the theorized mechanisms suggested in our hypotheses to hold, it is sufficient for managers to develop a perception of control, which would subsequently alter growth and exit behavior based on that perception regardless of whether this actually improves performance or not (March, 2010). Future research on perceptions of control among entrepreneurs at different stages of firm growth may serve to further illuminate these mechanisms.

An important facet of our theory and potential limitation is the nature of resources and the ways they are altered over time. The process of depletion and accumulation of organizational resources follows March and Shapira’s (1992) original theory. They define the term "resource” as intentionally general in their theory, including capital assets, political support, reputation, and other forms of capital. We limit our analysis to financial resources given the research context. Future research could expand on the potentially contingent effects of other types of resource slack for entrepreneurial decision making (George, 2005; Zimmerman and Zeitz, 2002).

Another limitation is the generalizability of our findings. We study the professional services sector where most new ventures operate (Haltiwanger et al., 2012), but entrepreneurs' attention to the survival or aspiration reference points may vary across industries. Some industries are riskier and can be characterized by on average low, but highly variable, profitability rates. Other industries are less risky with a moderate probability of success but lower variance in outcomes (Van de Ven et al., 1984). Professional services ventures belong to the latter type of industry, for which sales and returns are dictated by billable hours. This empirical setting represents an initial test for our hypotheses regarding growth but may limit generalizability as variability in performance may affect risk behavior. Future research on the 
aspiration-performance growth relationship could examine industry differences in risk distributions.

Our theory of variable risk preferences and focus of attention deal with two fundamental decisions for new ventures: to exit or to continue the venture and, contingent on continuation, to seek growth or not. Other important decisions are made during the early development of new ventures that may be affected by entrepreneurs' variable risk preferences and focus of attention (Mishina et al., 2004). Evidence for our prediction that age would increase risk preferences toward growth when close to the survival point (Hypothesis 1b) was not evident when we included controls for the Swedish economic downturn of 2002. This suggests that the framing effects suggested by reference-dependent models and escalation of commitment theory may be limited to more "normal” economic conditions. Future research can further examine external economic factors as part of their growth modelling and entrepreneurial risk preferences.

\subsection{Conclusions}

While much entrepreneurship research celebrates the well-known cases of rapidly growing ventures, most new ventures do not survive, and only a few grow. We outline and empirically test a theory of decision making that explains what triggers new ventures to exit and/or grow in size. New ventures’ age and size create important boundary conditions that affect entrepreneurs' preferences to exit or grow. We offer an explanation for erratic patterns of new venture development whereby path dependence can be explained by decision making based on two decision domains and venture age and size. 


\section{References}

Altman, E.I., 1968. Financial ratios, discriminant analysis and the prediction of corporate bankruptcy. Journal of Finance 23, 589-609.

Arora, A., Nandkumar, A., 2011. Cash-Out or Flameout! Opportunity Cost and Entrepreneurial Strategy: Theory, and Evidence from the Information Security Industry. Management Science 57, 1844-1860.

Audia, P.G., Greve, H.R., 2006. Less likely to fail: Low performance, firm size, and factory expansion in the shipbuilding industry. Management Science 52, 83-94.

Bamford, C.E., Dean, T.J., Douglas, T.J., 2004. The temporal nature of growth determinants in new bank foundings: implications for new venture research design. Journal of Business Venturing 19, 899-919.

Barron, D.N., West, E., Hannan, M.T., 1994. A time to grow and a time to die: Growth and mortality of credit unions in New York City, 1914-1990. American Journal of Sociology 100, 381-421.

Baum, R., Locke, E.A., 2004. The relationship of entrepreneurial traits, skill, and motivation to subsequent venture growth. Journal of Applied Psychology 89, 587-598.

Baum, R.J., Locke, E.A., Smith, K.G., 2001. A multidimensional model of venture growth. Academy of Management Journal 44, 292-303.

Bazerman, M.H., 1984. The relevance of Kahneman and Tversky's concept of framing to organizational behavior. Journal of Management 10, 333.

Berry, W.D., Golder, M., Milton, D., 2012. Improving tests of theories positing interaction. Journal of Politics 74, 653-671.

Bradley, S.W., Aldrich, H., Shepherd, D.A., Wiklund, J., 2011. Resources, environmental change, and survival: asymmetric paths of young independent and subsidiary organizations. Strategic Management Journal 32, 486-509.

Brambor, T., Clark, W.R., Golder, M., 2006. Understanding Interaction Models: Improving Empirical Analyses. Political Analysis 14, 63-82.

Bromiley, P., 2010. Looking at prospect theory. Strategic Management Journal 31, 1357-1370.

Busenitz, L., Barney, J., 1997. Difference between entrepreneurs and managers in large organizations: Biases and heuristics in strategic decision making. Journal of Business Venturing 12, 9-30.

Cassar, G., 2010. Are individuals entering self-employment overly optimistic? an empirical test of plans and projections on nascent entrepreneur expectations Strategic Management Journal 31, 822-840.

Chandler, G.N., McKelvie, A., Davidsson, P., 2009. Asset specificity and behavioral uncertainty as moderators of the sales growth - Employment growth relationship in emerging ventures. Journal of Business Venturing 24, 373-387.

Coad, A., Frankish, J., Roberts, R.G., Storey, D.J., 2013. Growth paths and survival chances: An application of Gambler's Ruin theory. Journal of Business Venturing 28, 615-632.

Cyert, R.M., March, J.G., 1963. A behavioral theory of the firm. Prentice-Hall, Englewood Cliffs, N.J.

Davidson, R., \& MacKinnon, J. G. 1981. Several tests for model specification in the presence of alternative hypotheses. Econometrica, 49(3): 781-793.

Davidsson, P., Steffens, P., Fitzsimmons, J., 2009. Growing profitable or growing from profits: Putting the horse in front of the cart? Journal of Business Venturing 24, 388-406. 
Delmar, F., Davidsson, P., Gartner, W.B., 2003. Arriving at the high-growth firm. Journal of Business Venturing 18, 189-216.

Delmar, F., McKelvie, A., Wennberg, K., 2013. Untangling the relationships among growth, profitability and survival in new firms. Technovation 33, 276-291.

Delmar, F., Shane, S., 2004. Legitimating first: organizing activities and the survival of new ventures. Journal of Business Venturing 19, 385-410.

Delmar, F., Wennberg, K. Hellerstedt, K. 2011. Endogenous growth through knowledge spillovers in entrepreneurship: an empirical test. Strategic Entrepreneurship Journal 5(3): 199-226.

Denrell, J., 2007. Adaptive learning and risk taking. Psychological Review 114, 177-187.

Desai, V.M., 2008. Constrained growth: How experience, legitimacy, and age influence risk taking in organizations. Organization Science 19, 594-608.

DeTienne, D., Shepherd, D.A., DeCastro, J., 2008. The fallacy of only the strong survive: The effects of extrinsic motivation on the persistence decisions for under-performing firms. Journal of Business Venturing 23, 528-546.

DeTienne, D.R., Shepherd, D.A., De Castro, J.O., 2008. The fallacy of “only the strong survive”: The effects of extrinsic motivation on the persistence decisions for under-performing firms. Journal of Business Venturing 23, 528-546.

Frankish, J.S., Roberts, R.G., Coad, A., Spears, T.C., Storey, D.J., 2012. Do entrepreneurs really learn? Or do they just tell us that they do? Industrial and Corporate Change.

George, G., 2005. Slack resources and the performance of privately held firms. Academy of Management Journal 48, 661-676.

Geroski, P.A., Mata, J., Portugal, P., 2010. Founding conditions and the survival of new firms. Strategic Management Journal 31, 510-529.

Gilbert, B.A., McDougall, P.P., Audretsch, D.B., 2006. New venture growth: A review and extension. Journal of Management 32, 926-950.

Gimeno, J., Folta, T.B., Cooper, A.C., Woo, C.Y., 1997. Survival of the fittest? Entrepreneurial human capital and the persistence of underperforming firms. Administrative Science Quarterly 42, 750-783.

Greenwood, R., Li, S.X., Prakash, R., Deephouse, D.L., 2005. Reputation, diversification, and organizational explanations of performance in professional service firms. Organization Science 16, 661-673.

Greve, H.R., 1998. Performance, aspirations and risky organizational change. Administrative Science Quarterly 43, 58-86.

Greve, H.R., 2003a. A behavioral theory of R\&D expenditures and innovations: Evidence from shipbuilding. Academy of Management Journal 46, 685-702.

Greve, H.R., 2003b. Organizational Learning from Performance Feedback : A Behavioral Perspective on Innovation and Change. Cambridge University Press, London.

Greve, H.R., 2008. A behavioral theory of firm growth: Sequential attention to size and performance goals. Academy of Management Journal 51, 476-494.

Gruber, M., 2010. Exploring the origins of organizational paths: Empirical evidence from newly founded firms. Journal of Management 36, 1143-1167.

Gruber, M., MacMillan, I.C., Thompson, J.D., 2012. From minds to markets. Journal of Management 38, 1421-1449.

Haltiwanger, J., Jarmin, R.S., Miranda, J., 2012. Who creates jobs? Small versus large versus young. Review of Economics and Statistics 95, 347-361. 
Heavey, C., Simsek, Z., 2015. Transactive memory systems and firm performance: An upper echelons perspective. Organization Science 26, 941-959.

Hitt, M.A., Biermant, L., Shimizu, K., Kochhar, R., 2001. Direct and moderating effects of human capital on strategy and performance in professional services firms: A resource-based perspective. Academy of Management Journal 44, 13-28.

Holland, D.V., Shepherd, D.A., 2013. Deciding to persist: Adversity, values, and entrepreneurs' decision policies. Entrepreneurship Theory and Practice 37, 331-358.

Hu, S., Blettner, D., Bettis, R.A., 2011. Adaptive aspirations: performance consequences of risk preferences at extremes and alternative reference groups. Strategic Management Journal 32, 1426-1436.

Jovanovic, B., 1982. Selection and the evolution of industry. Econometrica 50, 649-670.

Kahneman, D., Tversky, A., 1979. Prospect theory: An analysis of decision under risk. Econometrica 47, 263-291.

Kazanjian, R.K., Drazin, R., 1990. A stage-contingent model of design and growth for technology based new ventures. Journal of Business Venturing 5, 137-150.

Klepper, S., Sleeper, S., 2005. Entry by spinoffs. Management Science 51, 1291-1306.

Klotz, A.C., Hmieleski, K.M., Bradley, B.H., Busenitz, L.W., 2013. New venture teams: A review of the literature and roadmap for future research. Journal of Management 40(1), 226-255.

Lant, T., Mezias, S.J., 1992. A organizational learning model of convergence and reorientation. Organization Science 3, 47-71.

Le Mens, G., Hannan, M.T., Pólos, L., 2011. Founding conditions, learning, and organizational life chances: Age dependence revisited. Administrative Science Quarterly 56, 95-126.

Levinthal, D.A., March, J., 1981. A model of adaptive organizational search. Journal of Economic Behavior and Organization 2, 307-333.

Levinthal, D.A., March, J.G., 1993. The myopia of learning. Strategic Management Journal 14, 95.

Majumdar, S.K., 2004. The hidden hand and the license raj to an evaluation of the relationship between age and the growth of firms in India. Journal of Business Venturing 19, 107-125.

March, J.G., 2010. The Ambiguities of Experience. Cornell University Press, Ithaca, United States

March, J.G., Shapira, Z., 1987. Managerial erspectives on risk and risk taking. Management Science 33, 1404-1418.

March, J.G., Shapira, Z., 1992. Variable risk preferences and the focus of attention. Psychological Review 99, 172-183.

Mathias, B.D., Williams, D.W., Smith, A.R., 2015. Entrepreneurial inception: The role of imprinting in entrepreneurial action. Journal of Business Venturing 30, 11-28.

Miller, K.D., Chen, W.-R., 2004. Variable organizational risk preferences: Tests of the MarchShapira model. The Academy of Management Journal 47, 105-115.

Mishina, Y., Pollock, T.G., Porac, J.F., 2004. Are more resources always better for growth? Resource stickiness in market and product expansion. Strategic Management Journal 25, 1179-1197.

Naldi, L., Davidsson, P., 2014. Entrepreneurial growth: The role of international knowledge acquisition as moderated by venture age. Journal of Business Venturing 29, 687-703.

O'Brien, J.P., Folta, T.B., Johnson, D.R., 2003. A real options perspective on entrepreneurial entry in the face of uncertainty. Managerial and Decision Economics 24, 515-533. 
Ocasio, W., 1995. The enactment of economic adversity-a reconciliation of theories of failureinduced change and threat-rigidity. Research in Organizational Behavior 17, 287-331.

Pakes, A., Ericson, R., 1998. Empirical implications of alternative models of firm dynamics. Journal of Economic Theory 79, 1.

Payne, J.W., Bettman, J.R., 1992. Behavioral decision research: A constructive processing perspective. Annual Review of Psychology 43, 87.

Penrose, E., 1959. The Theory of the Growth of the Firm. Oxford University Press, Oxford.

Sarasvathy, S. D. 2001. Causation and effecuation: Toward a theoretical shift from economic inevitability to entrepreneurial contingency. Academy of Management Review, 26(2): 243263.

Singh, J.V. 1986. Performance, slack, and risk taking in organizational decision making. Academy of Management Journal, 29, 562-585.

Shepherd, D., Wiklund, J., 2009. Are ee comparing apples with apples or apples with oranges? Appropriateness of knowledge accumulation across growth studies. Entrepreneurship Theory and Practice 33, 105-123.

Shepherd, D.A., Williams, T.A., Patzelt, H., 2015. Thinking about entrepreneurial decision ,aking: Review and research agenda. Journal of Management 41, 11-46.

Shimizu, K., 2007. Prospect theory, behavioral theory, and the threat-rigidity thesis: Combanitive effects on organizational decisions to divest formely acquired units. Academy of Management Journal 50, 1495-1514.

Shinkle, G.A., 2012. Organizational aspirations, reference points, and goals: Building on the past and aiming for the future. Journal of Management 38, 415-455.

Sleesman, D.J., Conlon, D.E., McNamara, G., Miles, J.E., 2012. Cleaning up the big muddy: A meta-analytic review of the determinants of escalation of commitment. Academy of Management Journal 55, 541-562.

Sorensen, J., 2007. Bureaucracy and entrepreneurship: Workplace effects on entrepreneurial entry. Administrative Science Quarterly 52, 387-412.

Staw, B.M., 1976. Knee-deep in the big muddy: a study of escalating commitment to a chosen course of action. Organizational Behavior and Human Performance 16, $27-44$.

Staw, B.M., Hoang, H., 1995. Sunk costs in the NBA: Why draft order affects playing time and survival in professional basketball. Administrative Science Quarterly, 474-494.

Toft-Kehler, R., Wennberg, K. \& Kim, P. (2014). Practice makes perfect: Entrepreneurialexperience curves and venture performance. Journal of Business Venturing 29(4), 453-470.

Tversky, A., Fox, C.R., 1995. Weighing risk and uncertainty. Psychological Review 102, 269283.

Van de Ven, A.H., Hudson, R., Schroeder, D.M., 1984. Designing new business startups: Entrepreneurial, organizational, and ecological considerations. Journal of Management 10, 87.

Weber, E.U., Johnson, E.J., 2009. Mindful judgment and decision making. Annual Review of Psychology 60, 53-85.

Wennberg, K. 2009. Knowledge combinations and the survival of financial service ventures. Journal of Evolutionary Economics, 19(2): 259-276.

Wennberg, K., Wiklund, J., DeTienne, D., Cardon, M., 2010. Reconceptualizing entrepreneurial exit: Divergent exit routes and their drivers. Journal of Business Venturing 25, 361-375.

Whyte, G., 1993. Escalating commitment in individual and group decision making: A prospect theory approach. Organizational Behavior and Human Decision Processes 54, 430-455. 
Wiklund, J., Baker, T., Shepherd, D., 2010. The age-effect of financial indicators as buffers against the liability of newness. Journal of Business Venturing 25, 423-437.

Wiklund, J., Davidsson, P., Delmar, F., 2003. What do they think and feel about growth? An expectancy-value approach to small business managers' attitudes toward growth. Entrepreneurship Theory and Practice 27, 247-270.

Wiseman, R.M., Bromiley, P., 1996. Toward a model of risk in declining organizations: An empirical examination of risk, performance and decline. Organization Science 7, 524-543.

Wooldridge, J. M. 2002. Econometric Analysis of Cross Section and Panel Data. Cambridge, MA: The MIT Press.

Wright, M., \& Stigliani, I. 2013. Entrepreneurship and growth. International Small Business Journal, 31(1): 3-22.

Wu, B., Knott, A.M., 2006. Entrepreneurial risk and market entry. Management Science 52, 1315-1330.

Zimmerman, M.A., Zeitz, G.J., 2002. Beyond survival: Achieving new venture growth by building legitimacy. Academy of Management Review 27, 414-431. 